\title{
Influence of sublittoral microphytobenthos on the oxygen and nutrient flux between sediment and water: a laboratory continuous-flow study
}

\author{
Kristina Sundbäck ${ }^{1}$, Viveka Enoksson ${ }^{2}$, Wilhelm Granéli ${ }^{3}$, Karin Pettersson ${ }^{2}$ \\ ${ }^{1}$ Department of Marine Botany, University of Göteborg, Carl Skottsbergs Gata 22, S-413 19 Göteborg, Sweden \\ ${ }^{2}$ Department of Marine Microbiology, University of Göteborg, Carl Skottsbergs Gata 22, S-413 19 Göteborg, Sweden \\ ${ }^{3}$ Department of Limnology, University of Lund, PO Box 65, S-221 00 Lund, Sweden
}

\begin{abstract}
Influence of sublittoral microphytobenthos on the flux of oxygen and inorganic nutrients $(N, P, S i)$ at the sediment-water interface was studied using undisturbed cores of sandy and muddy sediment incubated in a laboratory continuous-flow system, either in darkness or with a 16/8 h L/D cycle at in situ light level during summer. Sediment was collected in July at $15 \mathrm{~m}$ depth in a non-tidal, stratified bay in SE Kattegat. To test whether the higher content of inorganic nutrients below the halocline, compared with surface waters, could stimulate microphytobenthic growth, 2 levels of nutrient concentrations were used. Diel variations were found in L/D cores, but not in darkened cores, for oxygen, dissolved inorganic nitrogen and phosphorus content in the water overlying the sediment. The flux of $\mathrm{NH}_{4}{ }^{+}, \mathrm{NO}_{3}{ }^{-}$and $\mathrm{PO}_{4}{ }^{3-}$ out of the sediment decreased during light periods and occasionally a net uptake was recorded. Light-induced $\mathrm{O}_{2}$ production, and correlations between $\Delta$ fluxes (differences between day and night fluxes of $\mathrm{O}_{2}$ and nutrients), chlorophyll a content and algal cell numbers in the sediment, indicate that the decreased outflux of IN and $\mathrm{PO}_{4}{ }^{3-}$ was mediated by photosynthetic organisms. Diel variations were not studied for silicon, but a significantly lower outflux, or even an uptake, of $\mathrm{Si}(\mathrm{OH})_{4}$ from L/D cores supports this conclusion. This suggests that diatoms play a major role in the nutrient flux between sediment and water. Also, the differences in pore-water nutrient gradients between L/D and dark cores point to the importance of sediment-associated organisms. Daily (24 h) net fluxes of nutrients were primarily out of the sediment, but the magnitude depended on both light conditions and sediment type. Daily net outflux was significantly lower in L/D cores than in darkened cores for all nutrients except $\mathrm{NO}_{3}{ }^{-}$in muddy cores and $\mathrm{NO}_{2}{ }^{-}$in sandy cores. Net uptake in L/D cores was recorded for $\mathrm{Si}(\mathrm{OH})_{4}$ and $\mathrm{NO}_{3}{ }^{-}$in sandy sediment. Outflux of nutrients was significantly higher from muddy sediments in comparison with sandy sediments (except $\mathrm{NO}_{3}{ }^{-}$), especially in permanent darkness. No significant effect of nutrient enrichment on the abundance of sublittoral benthic microalgae could be shown. Results suggest that microphytobenthos can influence sediment-water exchange of inorganic nutrients even at sublittoral depths, and when measuring nutrient flux in permanently darkened cores from depths around $15 \mathrm{~m}$ in the Kattegat, summer flux rates will be overestimated by a factor varying between 2 and 6 , depending on sediment type.
\end{abstract}

\section{INTRODUCTION}

Sediments in shallow coastal areas are important sites for mineralization and recirculation of nutrients from the particulate organic matter to the water mass (e.g. Nixon 1981, Balzer 1984, Jensen et al. 1990 and references therein). Until recently, the influence of sediment-associated microalgae on the nutrient flux between sediment and water had been largely overlooked, whereas other factors, such as heterotrophic microbial and faunal activity, have long been recognized (for references see Aller 1988, Henriksen \& Kemp
1988). Nutrient exchange between sediment and water has traditionally been studied in darkened cores or chambers, also for sediments in shallow waters, thus excluding the influence of photosynthetic organisms. In coastal waters shallow and/or clear enough to enable light penetration to the sediment surface, sedimentassociated microalgae (microphytobenthos) can be expected to influence exchange of nutrients at the sediment-water interface, and this possibility has also been discussed (Henriksen et al. 1980, Granéli \& Sundbäck 1985, Nowicki \& Nixon 1985, Asmus 1986, Granéli \& Sundbäck 1986, Simon 1988, Keizer et al. 
1989, Jensen et al. 1990). Thus, photosynthesis of benthic microalgae has been suggested as one of the mechanisms (besides faunal bioturbation) explaining why pore water nutrient profiles cannot be used to predict sediment-water flux rates during conditions when light reaches the sediment surface (Blackburn \& Henriksen 1983, Ullman \& Aller 1989). Consequently, some recent investigations, both in marine and fresh water areas, have aimed at demonstrating the effect of benthic microalgae on sediment-water nutrient flux by comparing flux rates under different light conditions (Andersen \& Kristensen 1988, Carlton \& Wetzel 1988, Kelderman et al. 1988, Sundbäck \& Granéli 1988, Rizzo 1990 ) or by manipulating benthic microalgal abundance in situ (Hansson 1989). Microalgal influence on sediment-water nutrient flux has been shown to be due both to nutrient uptake and the oxygenation of the sediment/water interface by microalgal photosynthesis (Jensen et al. 1984, Andersen \& Kristensen 1988, Carlton \& Wetzel 1988).

The question remains whether microbenthic autotrophs play a significant role in regulating sedimentwater nutrient fluxes in sediments at depths greater than a few meters. Considerable microphytobenthic biomass and primary productivity have been documented for depths of 15 to $20 \mathrm{~m}$ in coastal temperate areas (Bodin et al. 1985, Herndl et al. 1989, RiauxGobin et al. 1989). In a stratified bay in SE Kattegat (Laholm Bay) some of the highest values of microphytobenthic biomass and potential productivity were in fact found at 14 to $16 \mathrm{~m}$, i.e. at or just below the sharp halocline (Sundbäck \& Jönsson 1988). Better nutrient availability in sediments in deeper waters and in below-halocline waters, in combination with algal adaptation to low light levels, are some of the factors suggested to explain this type of vertical distribution of benthic microalgae (Stevenson \& Stoermer 1981, Sundbäck \& Jönsson 1988).

Our aim was to study the influence of sublittoral microphytobenthos on the flux of $\mathrm{O}_{2}$ and inorganic nutrients $(\mathrm{N}, \mathrm{P}, \mathrm{Si})$ at the sediment-water interface in a non-tidal, stratified bay by using undisturbed sediment cores incubated in a laboratory continuous-flow system at simulated in situ conditions of light, temperature and nutrients. We also tested whether the higher content of inorganic nutrients below the halocline, compared with surface waters, could stimulate microphytobenthic growth.

\section{MATERIALS AND METHODS}

Sampling. Sediment samples were taken by divers at a water depth of $15 \mathrm{~m}$ in the middle of Laholm Bay $\left(56^{\circ} 35^{\prime} \mathrm{E}, 12^{\circ} 50^{\prime} \mathrm{N}\right)$ on $31 \mathrm{July} 1986$ (Fig.1). For hydrography and sediment characteristics see Enoksson

\section{LAHOLM BAY}

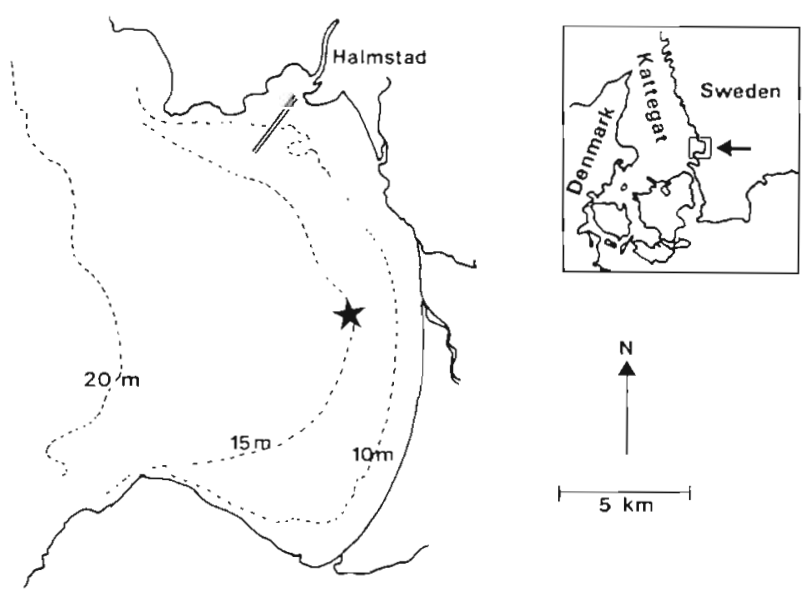

Fig. 1. Sampling site (star) in Laholm Bay, southeastern Kattegat

et al. (1990) and references therein. Altogether 30 cores, around $15 \mathrm{~cm}$ deep, were taken with perspex tubes $(8 \mathrm{~cm}$ ID) and placed in thermally insulated boxes. Surface water and water from ca $1 \mathrm{~m}$ above the bottom at the sampling site were collected with a 301 van Dorn water sampler.

Continuous-flow system. Sediment cores were stored in the dark at $15^{\circ} \mathrm{C}$ for $4 \mathrm{~d}$ prior to start of experiment. Surface water was filtered through $1.2 \mu \mathrm{m}$ Millipore membrane filters and concentrations of inorganic nutrients in both surface and bottom waters were analysed (see below). Cores that did not contain macrofauna were selected for the experiment. However, a few cores that did contain specimens of Cyprina islandica $(3.4$ to $6.8 \mathrm{~cm}$ length), were also used, after the mussels had been gently removed from the cores. In one core a $C$. islandica was found at the end of the experiment. No other macrofauna (animals $>5 \mathrm{~mm}$ ) was seen either at the start or at the termination of the experiment. The water in the tubes above the sediment (referred to as headspace water) was carefully replaced by 1.2 um-filtered surface water, with or without nutrient enrichments. Surface water enriched with inorganic nitrogen $\left(\mathrm{KNO}_{3}\right)$, phosphorus $\left(\mathrm{Na}_{2} \mathrm{HPO}_{4}\right)$, and silicon $\left(\mathrm{Na}_{2} \mathrm{SiO}_{3} \cdot 9 \mathrm{H}_{2} \mathrm{O}\right)$, corresponding to concentrations in the bottom water, was used instead of the original bottom water to avoid other differences (e.g. in salinity and content of organic substances). Nutrient concentrations of the inflowing surface water were: 0.1 to $0.8 \mu \mathrm{M} \mathrm{NH}_{4}{ }^{+}, 0.1$ to $0.5 \mu \mathrm{M} \mathrm{NO}_{3}^{-}, 0.05$ to $0.17 \mu \mathrm{M}$ $\mathrm{NO}_{2}{ }^{-}, 0.1$ to $0.2 \mu \mathrm{M} \mathrm{PO}_{4}{ }^{3-}$ and $3 \mu \mathrm{M} \mathrm{Si}(\mathrm{OH})_{4}$. Corresponding values of the 'bottom water' were: 0.1 to 0.6 uM NH${ }_{4}^{+}, 8$ to $9 u \mathrm{M} \mathrm{NO}_{3}^{-}, 0.04$ to $0.13 u \mathrm{M} \mathrm{NO}_{2}^{-}, 0.9$ to $1.3 \mu \mathrm{M} \mathrm{PO}_{4}{ }^{3-}$ and $55 \mu \mathrm{M} \mathrm{Si}(\mathrm{OH})_{4}$. Mean areal loading rates of nutrients for enriched water were 57 umol 
$\mathrm{NO}_{3}{ }^{-}, 7.3 \mu \mathrm{mol} \mathrm{PO}_{4}{ }^{3-}$ and $363 \mu \mathrm{mol} \mathrm{Si}(\mathrm{OH})_{4} \mathrm{~m}^{-2} \mathrm{~h}^{-1}$ (Si : N : P ratio $50: 8: 1$ ).

The 24 cores used for the sediment-water flux determinations were kept in water baths at $15^{\circ} \mathrm{C} \pm 0.2 \mathrm{C}^{\circ}$ (the temperature of bottom water on the sampling occasionl and the headspace water was connected to a flow through (Fig. 2). Water for refilling supply tanks during the experiment, was stored dark at $4{ }^{\circ} \mathrm{C}$. The headspace water (ca $500 \mathrm{ml}$ ) was gently stirred with a magnetic bar $(60 \mathrm{rpm})$ and continuously exchanged (ca $33 \mathrm{ml} \mathrm{h}^{-1}$ ) using multichannel peristaltic pumps, so that the total volume was renewed every 14 to $16 \mathrm{~h}$ with either surface water (12 cores) or 'bottom water' (12 cores) (Fig. 2). Twelve cores (6 with surface and 6 with
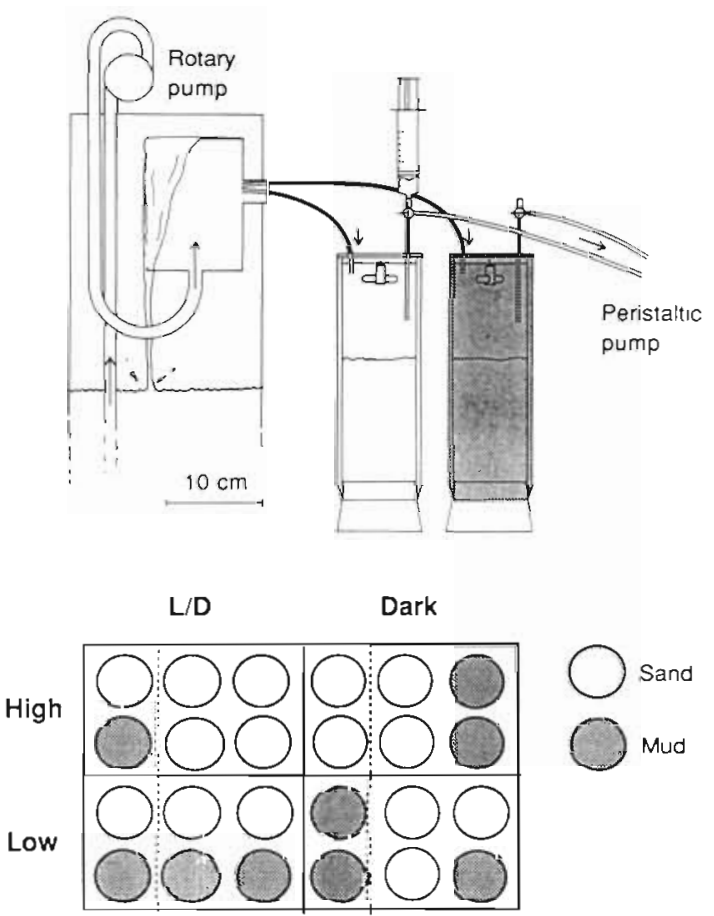

Fig. 2. Continuous-flow system and experimental design showing combinations of the 4 treatments: $L / D=16 / 8$ light dark cycle; Dark = permanent darkness; High $=$ P, N and Si enriched water ('bottom water'); Low = nutrient-poor surface water. Circles left of dashed lines: cores sampled more frequently (see text)

'bottom' water) were exposed to a $16 / 8 \mathrm{~h}$ light-dark cycle (referred to as $L / D$ cores) at a photon flux density of $20 \mu \mathrm{E} \mathrm{m}^{-2} \mathrm{~s}^{-1}\left(=1.2 \mathrm{E} \mathrm{m}^{-2} \mathrm{~d}^{-1}\right)$ simulating in situ light conditions in July at $15 \mathrm{~m}$ in Laholm Bay (Sundbäck \& Jönsson 1988). The other 12 cores (6 with surface and 6 with 'bottom' water) were kept dark (referred to as dark cores). Thus, the experiment comprised 4 treatments: dark cores with low or high nutrient concentration, and L/D cores with low or high nutrient concentration (Fig. 2). For practical reasons,
8 cores ( 2 for each treatment) were sampled more frequently. The curves for individual cores shown under 'Results' (Fig. 4 a to e) are based on these cores. The other cores ( 4 for each treatment), were sampled less frequently. Of the less frequently sampled cores (4 for each treatments), 8 cores were used for analyses of sediment and microphytobenthos in the middle of the experiment. For statistical purposes, the calculation of $24 \mathrm{~h}$ net flux rates were based on 16 cores (see under 'Statistical analysis'). The experiment was run for $14 \mathrm{~d}$ (5 to 18 Aug 1986).

Analyses of headspace water. Samples of inflowing and of headspace water were taken with syringes through valves twice a day, at the end of the light and dark period, respectively. $\mathrm{NH}_{4}{ }^{+}, \mathrm{NO}_{3}{ }^{-}, \mathrm{NO}_{2}{ }^{-}$and $\mathrm{PO}_{4}{ }^{3-}$ were analyzed using a Technicon Autoanalyzer as previously described by Enoksson \& Samuelsson (1987) and Enoksson (1987). Because of analytical problems, $\mathrm{NH}_{4}{ }^{+}$was measured only up to Day 8 . Silicon was analysed once a day according to the method described in Grasshoff et al. (1983), $\mathrm{O}_{2}$ concentration was measured with a Clark-type electrode (Hansatech, Kings Lynn, UK) using $2 \times 5 \mathrm{ml}$ subsamples. The electrode was calibrated by Winkler titrations. Flux rates were calculated according to the formula No. 6 in Propp et al. (1982), with the only difference being that we let outflux from the sediment be positive. The input concentration $\mathrm{C}_{0}$ (supply vessel) varied slightly with time, and therefore the mean value of the initial and final value for each period was used. A correction for the extraction of water samples for analysis was made as follows: For a period between 2 measurements, the final concentration in the extracted water sample and the initial concentration $\left(\mathrm{C}\left(\mathrm{t}_{0}\right)\right)$ was derived from the formula

$$
C\left(t_{0}\right)=\frac{(\omega-E) \cdot C_{b}+E \cdot C_{0}}{\omega}
$$

where $\omega=$ headspace volume; $\mathrm{E}=$ sample volume; $\mathrm{C}_{\mathrm{b}}$ $=$ concentration in the extracted water sample on the first occasion; $\mathrm{C}_{0}=$ input concentration. For the conditions used, this approximation deviated $\ll 1 \%$ from a corresponding logarithmic formula. Differences in flux rates between light and dark periods in L/D cores were calculated and are referred to as $\Delta$ flux. Mean flux rates for $24 \mathrm{~h}$ periods ( $=24 \mathrm{~h}$ net flux) were calculated as

$$
\frac{\text { Flux }_{\text {dark period }}+2 \cdot \text { Flux }_{\text {light period }}}{3}
$$

Analyses of sediment characteristics, pore water and microphytobenthos. Data on sediment variables rely on analyses of cores that were sliced before (2 cores), in the middle ( 8 cores on Days 6 and 7 ) and at the end of the experiment (16 cores, Day 13-14). The topmost $1.5 \mathrm{~cm}$ of each sediment core was sliced into 2 
layers $(0$ to $0.5 \mathrm{~cm}$ and 0.5 to $1.5 \mathrm{~cm}$ ) and subsamples for water content, particulate carbon (PC), nitrogen (PN), chlorophyll a content and number of algal cells were taken from the homogenized slices using cut-off $2 \mathrm{ml}$ syringes. Pore water was obtained from the remainder of each slice by centrifugation at $2000 \mathrm{rpm}$ and filtration through glass fibre filters. The reliability of the subsampling for chlorophyll and pheopigment determination was tested by analysing 15 replicate samples taken from the same slice. The coefficient of variation was $9.4 \%$ for chlorophyll a and $15.9 \%$ for pheopigment. Water content was measured by drying sediment at $105^{\circ} \mathrm{C}$. PC and PN were analysed using a Carlo Erba 1106 CHN analyser. Pore water samples were analysed for inorganic nutrients as described earlier.

Chlorophyll a content in the top $0.5 \mathrm{~cm}$ sediment was measured spectrophotometrically according to Lorenzen (1967) after extraction with $90 \%$ acetone overnight followed by 5 min ultrasonication. The number of living autotrophic cells in the top $0.5 \mathrm{~cm}$ was counted in a Bürker counting chamber using epifluorescence microscopy (Sundbäck et al. 1990).

Statistical analysis. The fact that the sediment cores represented 2 clearly different types of sediment (see under 'Results') added an unexpected source of variation to the data sets. The 2 sediment types were not evenly distributed among the 4 treatments (Fig. 2), hampering the statistical analyses, and only 16 cores could be used in the Newman-Keuls multiple comparison test (NK). Average values given in the text comprise all available cores. To reduce non-normality of data and heterogeneity of variances, data were transformed as $\ln (x+1)$ or $\overline{x+1}$ (see further Green 1979) before subjected to the NK-tests. In cases where the transformation was not successful, the non-parametric Wilcoxon signed rank test was applied. In some cases the non-parametric Mann-Whitney U-test (M-W Utest) was also used. Unless otherwise stated, differences are accepted as significant when $\mathrm{p}<0.05$.

\section{RESULTS}

\section{Sediment characteristics}

Although all sediment cores were taken within a distance of less than $50 \mathrm{~m}$ in Laholm Bay, 2 clearly different types of sediment were obtained: sand with an average water content of $30 \%$ ( 15 cores) and mud with a water content of $90 \%$ ( 9 cores) (Table 1 ). The contents of particulate carbon and nitrogen were an order of magnitude higher in the muddy than in the sandy sediment, but the mean $\mathrm{C} / \mathrm{N}$ mole ratio was about the same for both sediment types (9.5 to 9.7) (Table 1).

\section{Pore water}

The mean inorganic nutrient concentration in the pore water of the top $0.5 \mathrm{~cm}$ did not differ significantly between the 2 sediment types, except for $\mathrm{PO}_{4}{ }^{3-}$. The concentration of $\mathrm{PO}_{4}{ }^{3-}$ was significantly higher $(\mathrm{M}-\mathrm{W}$ $U$-test) in sandy than in muddy sediment (Table 1 ). This resulted in a lower mean $\mathrm{N}: \mathrm{P}$ ratio $(8: 1)$ for the sandy than for the muddy sediment $(22: 1)$ (Table 1 ).

Values from 16 cores were used to illustrate profiles of inorganic nutrients, using mean concentrations for

Table 1. Contents of water (not corrected for salinity), carbon (PC), nitrogen (PN), chlorophyll a, pheopigment, number of microalgal cells, and inorganic nutrient concentrations in pore water in the top $5 \mathrm{~mm}$ of 2 types of sediment used in the experiment

\begin{tabular}{|c|c|c|c|c|c|c|}
\hline \multirow[t]{2}{*}{ Characteristic } & \multicolumn{3}{|c|}{ Sand } & \multicolumn{3}{|c|}{ Mud } \\
\hline & Mean & $\mathrm{SD}$ & $(\mathrm{n})$ & Mean & SD & (n) \\
\hline Water content \% & 32.1 & $\pm \quad 5.4$ & (17) & 89.3 & \pm 2.4 & (9) \\
\hline PC, $u$ mol g $g^{-i}$ dry wt & 253.6 & \pm 105.3 & (7) & 3675.1 & \pm 127.4 & (4) \\
\hline PN, $\mu m o l g^{-1}$ dry wt & 26.8 & \pm 11.1 & (7) & 379.7 & \pm 22.0 & $(4)$ \\
\hline $\mathrm{C}: \mathrm{N}$ mole ratio & 9.5 & 0.3 & (7) & 9.7 & 0.3 & (4) \\
\hline Chl a, $\mathrm{mg} \mathrm{m}^{-2}$ & 31.2 & 16.3 & (17) & 87.5 & 54.9 & (9) \\
\hline Pheopigment, $\mathrm{mg} \mathrm{m}^{-2}$ & 26.5 & 10.9 & (17) & 37.5 & 15.0 & (9) \\
\hline Algal cells, $\times 10^{6} \mathrm{~cm}^{-2}$ & 0.66 & 0.24 & (15) & 1.58 & \pm 0.71 & (7) \\
\hline \multicolumn{7}{|l|}{ Conc. in pore water, $\mu \mathrm{M}$ : } \\
\hline $\mathrm{PO}_{4}{ }^{3-}$ & 7.1 & 3.6 & $(10)$ & 2.9 & 0.9 & (6) \\
\hline $\mathrm{NH}_{4}^{-}$ & 52.8 & 21.7 & $(10)$ & 58.6 & 30.2 & (4) \\
\hline $\mathrm{NO}_{3}^{-}$ & 2.9 & 2.0 & $(20)$ & 2.5 & 2.5 & (6) \\
\hline $\mathrm{NO}_{2}^{-}$ & 1.3 & \pm 1.3 & (10) & 1.8 & 1.4 & (6) \\
\hline $\mathrm{Si}(\mathrm{OH})_{4}$ & 233.1 & $\pm \quad 72.4$ & (10) & 175.9 & 54.2 & (6) \\
\hline Si:N:P & $32: 8: 1$ & & & $60: 22: 1$ & & \\
\hline
\end{tabular}



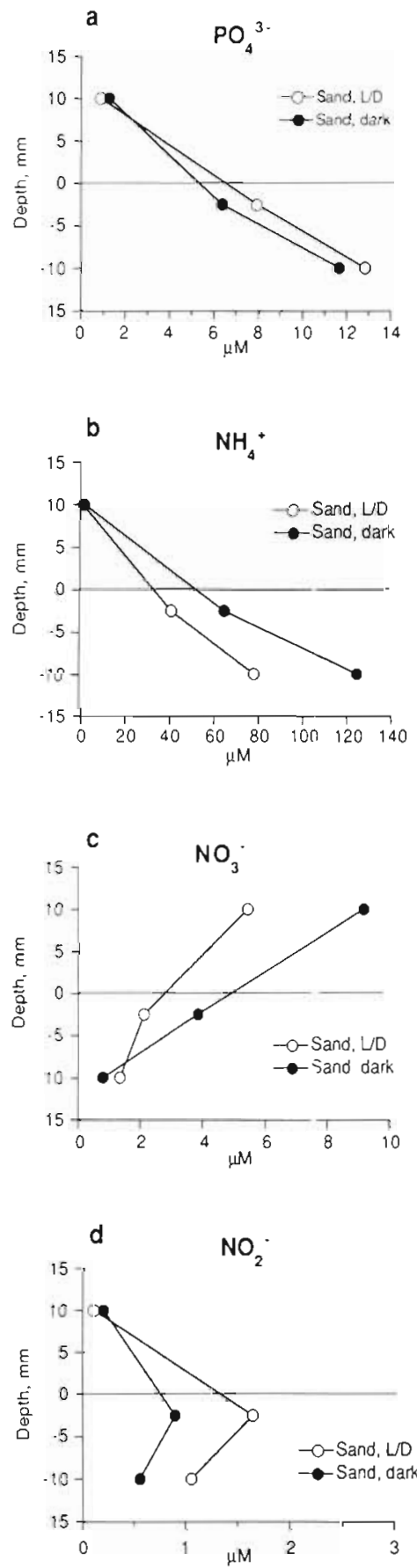

Fig. 3. Nutrient profiles for $L / D$ and dark cores of sandy and muddy sediment. Values based on mean concentrations of headspace water (above 0-line) and pore water from the 0 to $0.5 \mathrm{~cm}$ and 0.5 to $1.5 \mathrm{~cm}$ sediment layers. Sand $\mathrm{L} / \mathrm{D}, \mathrm{n}=5$; sand dark, $\mathrm{n}=5$; mud $L / D, n=3 ;$ mud dark, $\mathrm{n}=3$. For treatments see Fig. 2

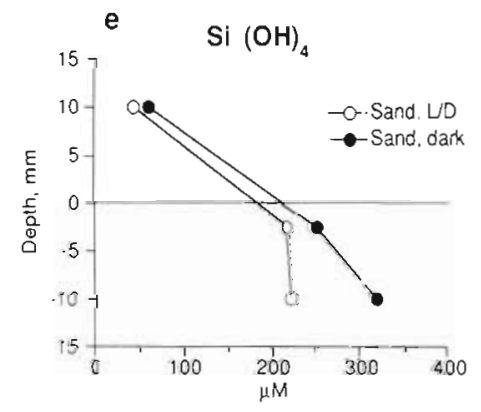


the headspace water, and for pore water from the 0 to $0.5 \mathrm{~cm}$ and 0.5 to $1.5 \mathrm{~cm}$ sediment layers (Fig. 3). For nitrate, ammonium (both sand and mud), and silica (only sand), there was a tendency for less steep gradients in L/D cores, when compared with dark cores (Fig. 3b, c, e). This tendency could, however, be statistically shown only for $\mathrm{NH}_{4}^{+}$in sandy sediment (M-W Utest, $p=0.05$ ). No similar trend was seen for $\mathrm{PO}_{4}{ }^{3-}$, but the upper part of the gradient was less steep for muddy sediment, when compared with sandy sediment (Fig. 3a). $\mathrm{A} \mathrm{NO}_{2}{ }^{-}$peak in the 0 to $0.5 \mathrm{~cm}$ layer was observed for both sandy and muddy light cores, as well as for sandy dark cores. The accumulation of nitrite in the headspace water of muddy dark cores (Fig. 5e) resulted in a steeply decreasing $\mathrm{NO}_{2}{ }^{-}$gradient.

\section{Chlorophyll $a$ and microphytobenthic abundance}

At the termination of the experiment chlorophyll a content of the top $0.5 \mathrm{~cm}$ sediment was 3 times higher in the muddy than in the sandy sediment (significant difference with $\mathrm{M}-\mathrm{W}$ U-test, $\mathrm{p}<0.009$ ) (Table 1). Nutrient additions did not significantly affect pigments or cell numbers. Although chlorophyll a values were lower in dark cores than in $\mathrm{L} / \mathrm{D}$ cores (mean values 24 vs $33 \mathrm{mg} \mathrm{m}^{-2}$ in sand and 65 vs $116 \mathrm{mg} \mathrm{m}^{-2}$ in mud), the difference was not significant (M-W U-test). Pheopigment content was slightly higher in muddy sediment. but did not vary significantly ( $M-W$ U-test) between treatments (Table 1).

The number of viable (fluorescing) cells varied between 0.4 and $3 \times 10^{6} \mathrm{~cm}^{-2}$. The number of algal cells was positively correlated with chlorophyll a content $(\mathrm{r}=$ $0.95, n=20, p<0.005$ ). Average number of viable cells was 2.5 times higher in the muddy sediment $\left(1.58 \times 10^{6}\right.$ cells $\left.\mathrm{cm}^{-2}\right)$ than in the sandy sediment $\left(0.66 \times 10^{6}\right.$ cells $\mathrm{cm}^{-2} ; \mathrm{M}$-W U-test, $\mathrm{p}<0.002$ ). Significantly higher algal cell numbers (almost by a factor of 2) were also found in sandy L/D cores when compared with sandy dark cores (M-W U-test, $p<0.05)$. In sandy sediment, the highest values for chlorophyll a (61 $\left.\mathrm{mg} \mathrm{m}^{-2}\right)$ and number of algal cells $\left(1.13 \times 10^{6} \mathrm{~cm}^{-2}\right)$ were found in a core that contained the mussel Cyprina islandica.

\section{Oxygen flux}

There was diel variation in the $\mathrm{O}_{2}$ concentrations of the headspace water in $L / D$ cores, but not in dark cores. The minimum $\mathrm{O}_{2}$ concentrations in the dark cores were around 150 umol $\mathrm{O}_{2} \mathrm{l}^{-1}$, while for the L/D cores the range of $\mathrm{O}_{2}$ concentrations was 200 to $3504 \mathrm{~mol} \mathrm{O} \mathrm{O}^{-1}$ The $\mathrm{O}_{2}$ saturation value at $15^{\circ} \mathrm{C}$ and $20 \%$ is $279 \mu \mathrm{mol}$ $\mathrm{O}_{2} I^{-1}$ Thus, extreme values for the $\mathrm{O}_{2}$ content above the sediment were approximately 50 to $125 \%$ of the saturation value.

The maximum $\Delta \mathrm{O}_{2}$ flux (light minus dark flux rate in $\mathrm{L} / \mathrm{D}$ cores) was as high as $1400 \mu \mathrm{mol} \mathrm{O} \mathrm{m}^{-2} \mathrm{~h}^{-1}$, a value that was obtained in a muddy core. The flux in this core varied between a net $\mathrm{O}_{2}$ production of $800 \mu \mathrm{mol} \mathrm{O} \mathrm{m}^{-2}$ $\mathrm{h}^{-1}$ and a net consumption of $1080 \mu \mathrm{mol} \mathrm{O} \mathrm{O}^{-2} \mathrm{~h}^{-1}$ (Fig. 4a). $\Delta \mathrm{O}_{2}$ flux was also high in the core containing a mussel $\left(960 \mu \mathrm{mol} \mathrm{m} \mathrm{m}^{-2} \mathrm{~h}^{-1}\right)$ (Fig. 4 a). The average $\Delta \mathrm{O}_{2}$ flux was $290 \pm 220$ (SD) $\mu \mathrm{mol} \mathrm{m} \mathrm{m}^{-2} \mathrm{~h}^{-1}$ if these 2 cores were excluded. The $\mathrm{O}_{2}$ consumption during night in the L/D cores (mean $560 \mu \mathrm{mol} \mathrm{m}^{-2} \mathrm{~h}^{-1}$ ) was not significantly different (M-W U-test) from the $\mathrm{O}_{2}$ consumption

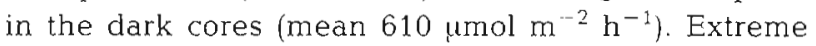
recordings of $\mathrm{O}_{2}$ consumption for dark cores were 240 and 1480 umol $\mathrm{m}^{-2} \mathrm{~h}^{-1}$ ).

The mean $24 \mathrm{~h}$ net $\mathrm{O}_{2}$ uptake was always lower for the $\mathrm{L} / \mathrm{D}$ cores $\left(290 \mu \mathrm{mol} \mathrm{m} \mathrm{m}^{-2} \mathrm{~h}^{-1}\right.$ ) than for dark cores (600 umol $\mathrm{m}^{-2} \mathrm{~h}^{-1}$ ) (Fig. 5a). The difference was significant from Day 9 and onwards for muddy cores (NK) but never for sandy cores (NK). Muddy dark cores consumed, on an average, more $\mathrm{O}_{2}\left(670 \mu \mathrm{mol} \mathrm{m} \mathrm{m}^{-2} \mathrm{~h}^{-1}\right)$ than sandy dark cores (550 $\mu \mathrm{mol} \mathrm{m}^{-2} \mathrm{~h}^{-1}$ ), mainly due to a significant (nearly 2 -fold) difference during the latter part of the experiment (NK). Higher nutrient levels in the 'bottom' water did not affect $\mathrm{O}_{2}$ exchange, neither in dark nor in L/D cores (NK).

\section{Flux of inorganic phosphorus}

Fluxes of $\mathrm{PO}_{4}{ }^{3-}$ showed diel variations in $\mathrm{L} / \mathrm{D}$ cores, with lower flux out of the sediment, or uptake by the sediment, during the light period (Fig. 4b). No diel patterns were observed in the dark cores. The highest $\triangle \mathrm{PO}_{4}{ }^{3-}$ flux rates of 3 to $4 \mu \mathrm{mol} \mathrm{m}{ }^{-2} \mathrm{~h}^{-1}$ (dark minus light flux rates in $\mathrm{L} / \mathrm{D}$ cores) were measured in the one extreme muddy core and in the sandy core with a mussel. The average $\Delta \mathrm{PO}_{4}{ }^{3--}$ flux for the rest of the $\mathrm{L} / \mathrm{D}$ cores was $0.6 \pm 0.8$ (SD) umol $\mathrm{m}^{-2} \mathrm{~h}^{-1}$. The $\mathrm{L} / \mathrm{D}$ treatment also affected the night values of the efflux; during the latter part of the experiment the dark cores released $2.5 \mathrm{~mol} \mathrm{~m}{ }^{-2} \mathrm{~h}^{-1}$ more $\mathrm{PO}_{4}{ }^{3-}$ (i.e. 2 to 3 times more) than the L/D cores during night

The $24 \mathrm{~h}$ net outflow of $\mathrm{PO}_{4}{ }^{3-}$ in muddy dark cores increased significantly with time (NK), being nearly 3 times higher ( 3 to 7 umol m-2 $\mathrm{h}^{-1}$ ) than the net outflow from $L / D$ cores $\left(0\right.$ to $\left.3 \mu \mathrm{mol} \mathrm{m} \mathrm{m}^{-2} \mathrm{~h}^{-1}\right)$ during the latter part of the experiment (NK) (Fig. 5b). A significant difference between $L / D$ and dark cores was also found for sandy sediment (NK), but mean flux rates were. both over time and for single cores, less than 2.2 umol $\mathrm{m}^{-2} \mathrm{~h}^{-1}$ (Fig. 5b). Muddy dark cores released about 3 times (NK) more $\mathrm{PO}_{4}{ }^{3-}$ than sandy dark cores during the latter part of the experiment (Fig. 5b). 

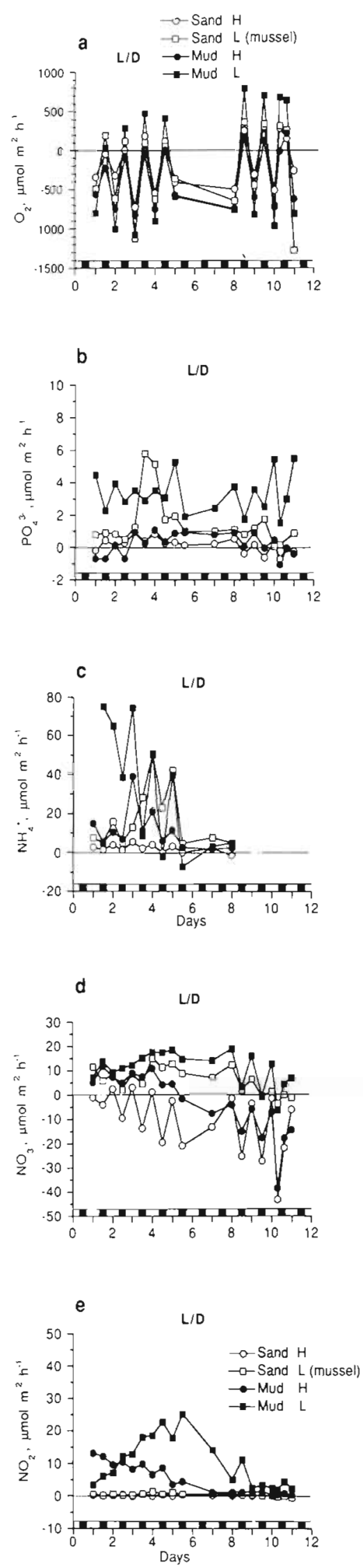
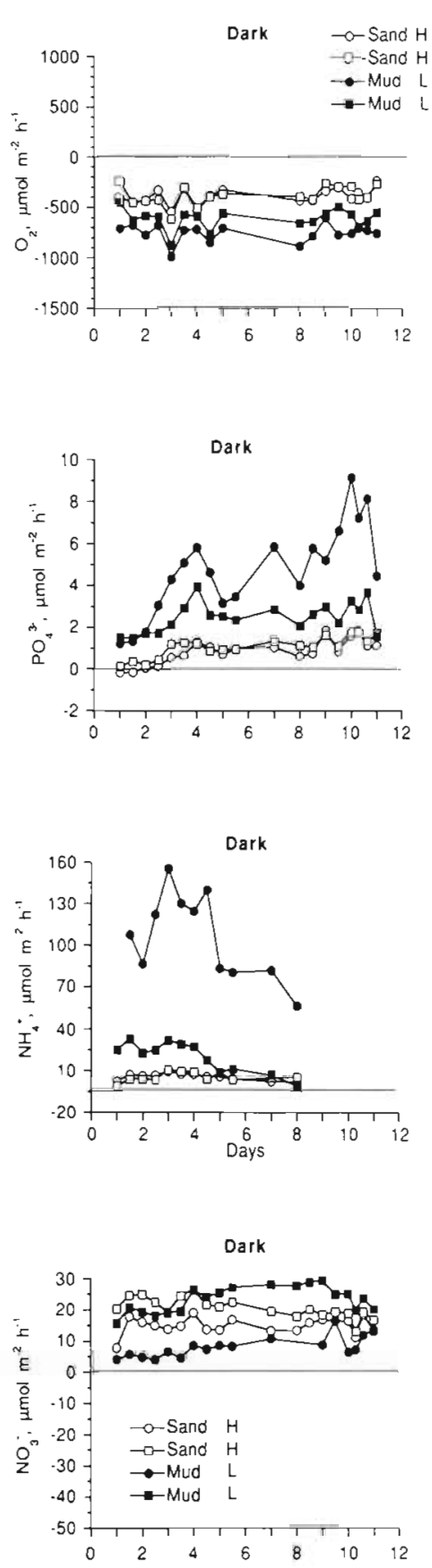

Fig. 4. Flux of oxygen (a), phosphate (b), ammonium, note different scales (c), nitrate (d) and nitrite (e) shown for individual L/D and dark cores measured twice a day. Dark squares on horizontal axes denote dark periods during the L/D cycle. $\mathrm{H}=$ high, $\mathrm{L}=$ low. For treatments see Fig. 2 

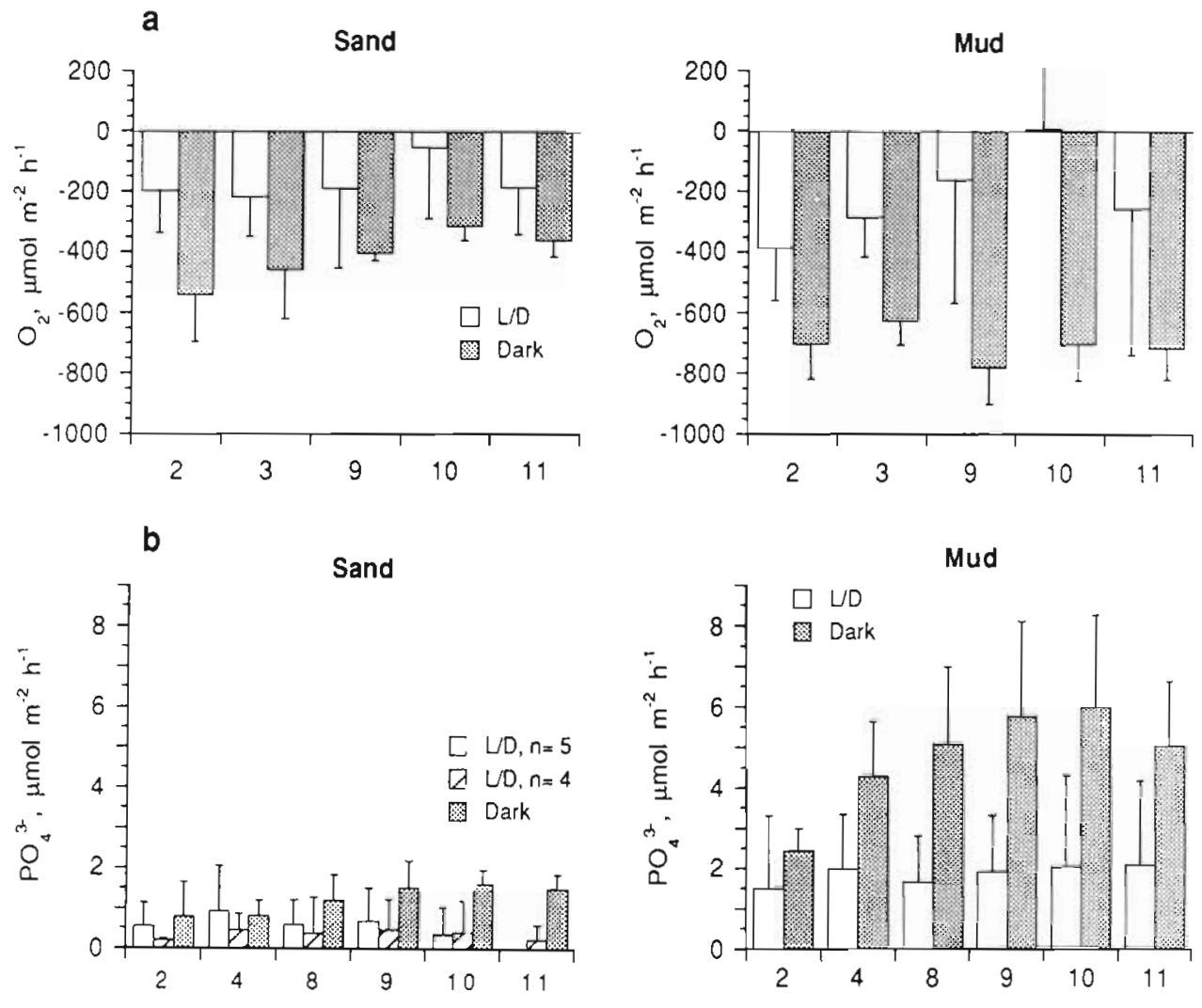

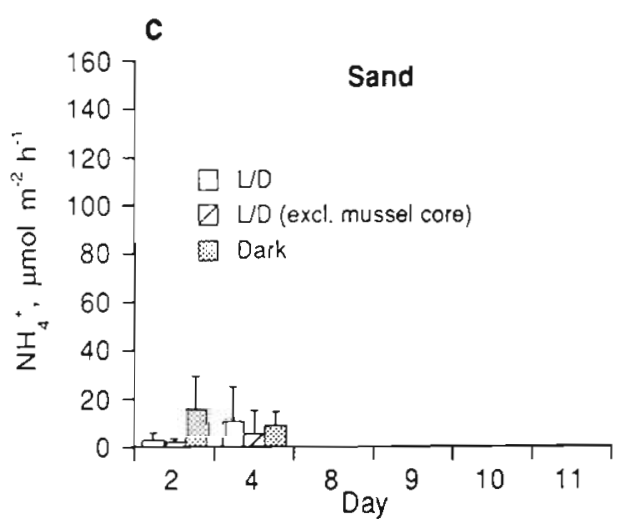

Flux of inorganic nitrogen

Ammonium

Fluxes of $\mathrm{NH}_{4}^{+}$exhibited strong diel variations in muddy $\mathrm{L} / \mathrm{D}$ cores, with a mean $\Delta \mathrm{NH}_{4}{ }^{+}$-flux of $22 \pm 14$ $\mu \mathrm{mol} \mathrm{m}{ }^{-2} \mathrm{~h}^{-1}$ and an extreme $\Delta$ flux of $65 \mu \mathrm{mol} \mathrm{m}{ }^{-2} \mathrm{~h}^{-1}$ (Fig. 4c; data on $\mathrm{NH}_{4}{ }^{+}$missing after Day 8). In sandy sediment, $\Delta \mathrm{NH}_{4}{ }^{+}$flux rate averaged $1.0 \pm 2.4$ (SD) umol $\mathrm{m}^{-2} \mathrm{~h}^{-1}$, excluding the core containing a mussel, for which $\Delta$ flux was up to $40 \mu \mathrm{mol} \mathrm{m} \mathrm{m}^{-2} \mathrm{~h}^{-1}$ (Fig. 4c). The direction of the flux was, for all cores, mainly out of the sediment, although uptake of less than $7 \mu \mathrm{mol} \mathrm{m} \mathrm{m}^{-2}$

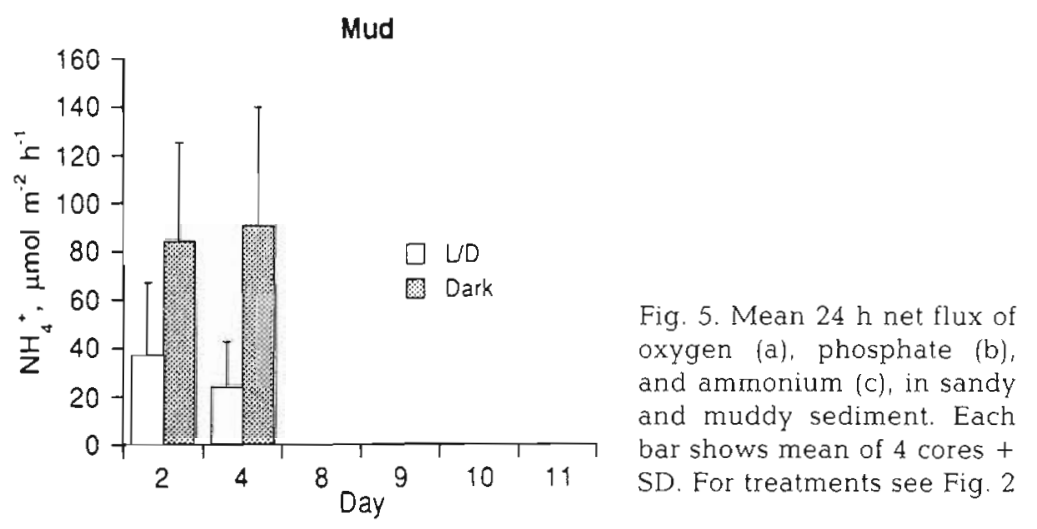

$\mathrm{h}^{-1}$ was also noted during light pericds. The highest rate of $\mathrm{NH}_{4}^{+}$efflux, $160 \mu \mathrm{mol} \mathrm{m}{ }^{-2} \mathrm{~h}^{-1}$, was measured in a dark muddy core, the maximum value being only 54 umol $\mathrm{m}^{-2} \mathrm{~h}^{-1}$ for sandy cores.

In muddy sediments, 24 h net $\mathrm{NH}_{4}{ }^{+}$flux rates were on average 3 times higher in dark cores (20 to $120 \mu \mathrm{mol}$ $\mathrm{m}^{-2} \mathrm{~h}^{-1}$ ) than in L/D cores (10 to $50 \mu \mathrm{mol} \mathrm{m} \mathrm{m}^{-2} \mathrm{~h}^{-1}$ ) (significant difference, Wilcoxon-test, $\mathrm{p}<0.001$ ) (Fig. 5c). In sandy cores, a significant difference between $\mathrm{L} / \mathrm{D}$ (0 to $12 \mu \mathrm{mol} \mathrm{m} \mathrm{m}^{-2} \mathrm{~h}^{-1}$ ) and dark cores ( 6 to $18 \mu \mathrm{mol}$ $\left.\mathrm{m}^{-2} \mathrm{~h}^{-1}\right)(\mathrm{NK})$ was found when the mussel core was excluded (Fig. 5c). The $\mathrm{NH}_{4}{ }^{+}$flux from muddy dark sediment was 20 to $120 \mu \mathrm{mol} \mathrm{m} \mathrm{m}^{-2} \mathrm{~h}^{-1}$, while the flux 

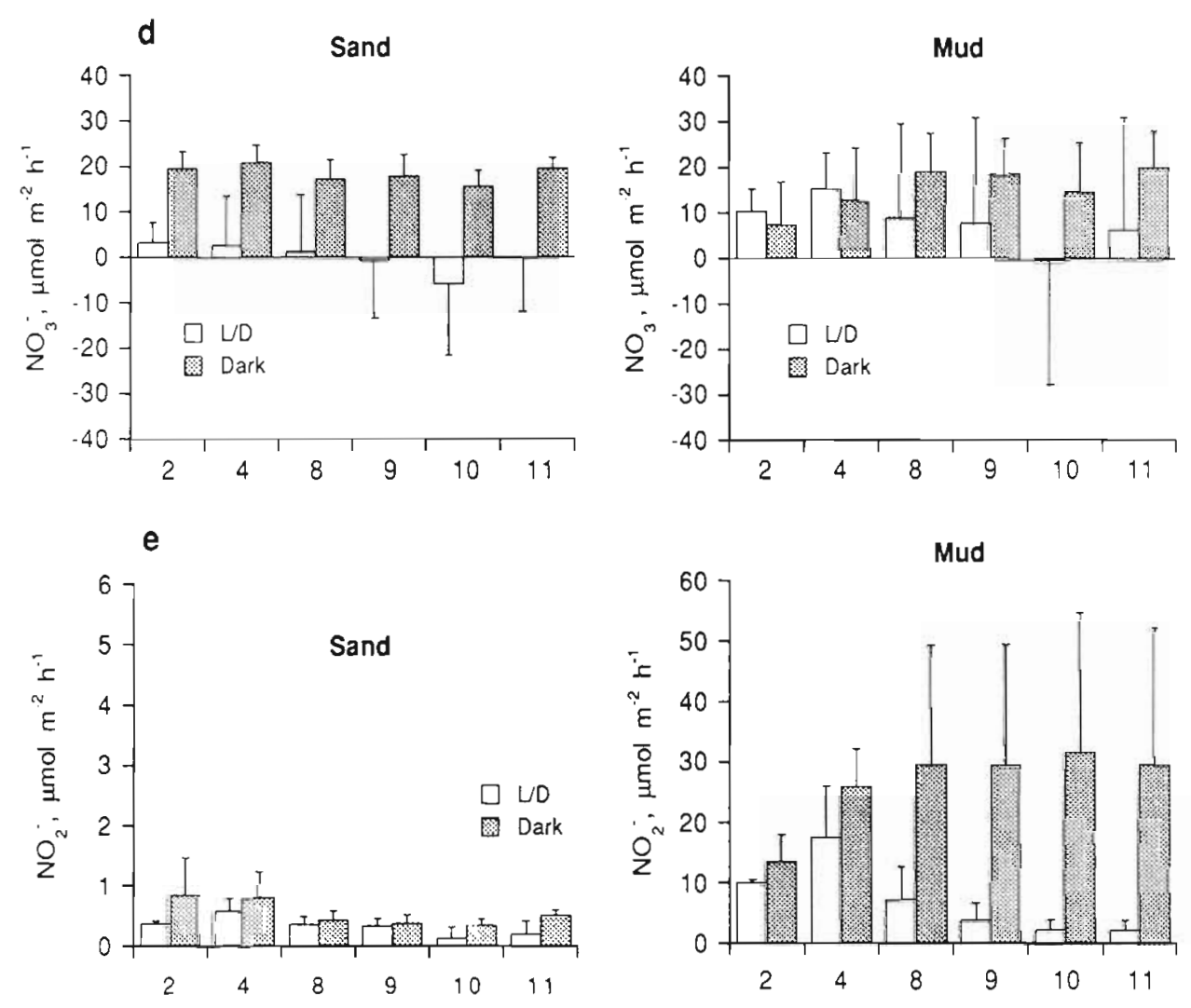

Fig. 5 (continued). Mean $24 \mathrm{~h}$ net flux of nitrate (d), nitrite (e) and silica (f) in sandy and muddy sediment
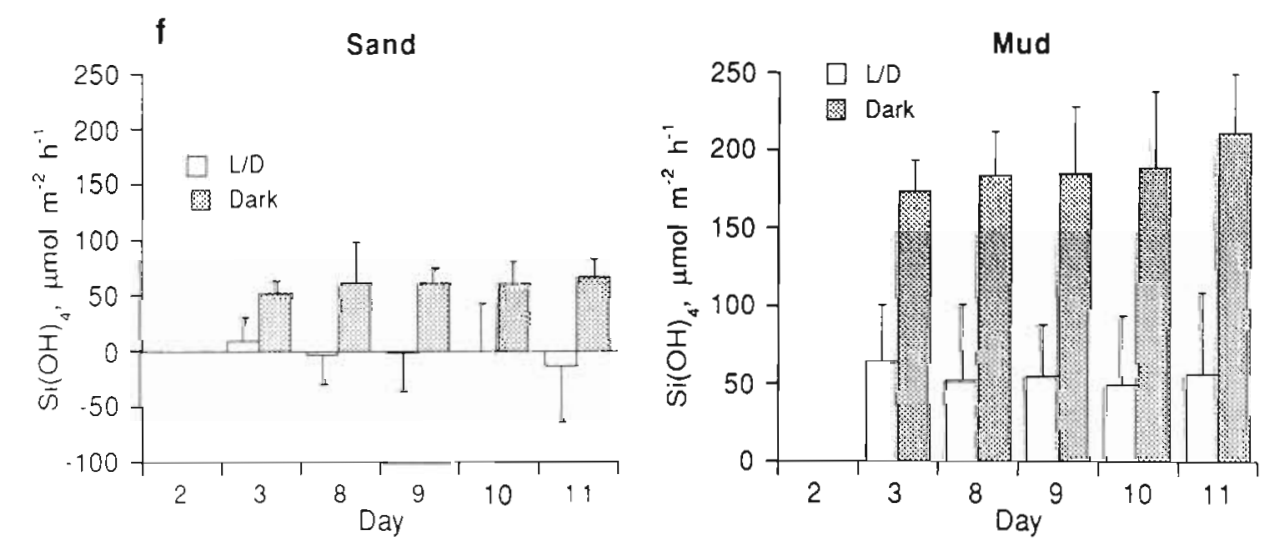

from sandy dark sediment generally was 5 to $20 \mu \mathrm{mol}$ $\mathrm{m}^{-2} \mathrm{~h}^{-1}$ (Fig. 5c).

Nitrate

The $\mathrm{NO}_{3}{ }^{-}$flux in the $\mathrm{L} / \mathrm{D}$ cores exhibited diel variation with an amplitude that increased with time. Maximum $\Delta \mathrm{NO}_{3}{ }^{-}$flux rate corresponded to an uptake of 40 $\mu \mathrm{mol} \mathrm{m}^{-2} \mathrm{~h}^{-1}$ during day and an insignificant flux rate during night (Fig. 4d). Mean $\Delta$ flux rates were similar in sandy and muddy cores, averaging $9 \pm 9$ (SD) $\mu \mathrm{mol}$ $\mathrm{m}^{-2} \mathrm{~h}^{-1}$ during the latter part of the experiment. In the dark cores, no diel flux variations, and no changes in flux rates over the experimental period were observed. $\mathrm{NO}_{3}{ }^{-}$flux out of the sediment varied between 4 to 29 $\mu \mathrm{mol} \mathrm{m} \mathrm{m}^{-2} \mathrm{~h}^{-1}$ among cores.

Although the $24 \mathrm{~h}$ net fluxes generally were higher for the dark cores than the L/D cores, this difference was only significant in sandy cores (Wilcoxon test, $\mathrm{p}<$ 0.001 ), the dark ones releasing at least 4 times as much $\mathrm{NO}_{3}{ }^{-}$as the $\mathrm{L} / \mathrm{D}$ cores (Fig $5 \mathrm{~d}$ ). A significant difference between sand and mud was only recorded on one occasion when sandy dark cores released $\mathrm{NO}_{3}{ }^{-}$at a significantly higher rate than the muddy dark cores (NK). 
Nitrite

Rates of $\mathrm{NO}_{2}{ }^{-}$efflux were lower than $1.5 \mu \mathrm{mol} \mathrm{m} \mathrm{m}^{-2}$ $\mathrm{h}^{-1}$ in sandy cores, but in muddy cores they were on an average 20 times higher ( 5 to $31 \mu \mathrm{mol} \mathrm{m}^{-2} \mathrm{~h}^{-1}$ ), both for L/D and dark treatments (Fig. 4e). In muddy cores $\mathrm{NO}_{2}{ }^{-}$fluxes were similar to $\mathrm{NO}_{3}{ }^{-}$fluxes. Small diel flux variations were observed in both sandy and muddy $L / D$ cores, most often showing the largest outflux during the light period, unlike $\mathrm{NO}_{3}{ }^{-}, \mathrm{NH}_{4}{ }^{+}$, and $\mathrm{PO}_{4}{ }^{3-}$ fluxes that were usually highest during the dark period.

For 24 h net fluxes, there was a significant difference (NK) between L/D and dark treatments in muddy sediment during the latter part of the experiment, but not in sandy sediment (Fig. 5e). The difference found in the muddy cores was a consequence of a significantly (NK) increased efflux from the dark cores (from Day 2) and a decreased efflux from L/D cores (after Day 4).

In muddy, but not in sandy cores, there was a strong correlation between the efflux of $\mathrm{NO}_{3}{ }^{-}$and $\mathrm{NO}_{2}{ }^{-}$out of the dark cores on Day 2 ( $\mathrm{r}=0.99, \mathrm{p}<0.001, \mathrm{n}=5$ ). However, $\mathrm{NO}_{2}{ }^{-}$efflux did not correlate with $\mathrm{NO}_{3}{ }^{-}$ concentration in the headspace waters. In many cores there was a tendency for the peak of $\mathrm{NO}_{2}{ }^{-}$efflux to occur after the peak of $\mathrm{NH}_{4}{ }^{+}$efflux and therefore, on no single occasion was there a clear relation between these 2 nutrients. Instead, a significant correlation was obtained between the maximum efflux rate of $\mathrm{NO}_{2}{ }^{-}$for each core and the early (Day 2$)$ efflux rate for $\mathrm{NH}_{4}{ }^{+}(\mathrm{r}=$ $0.94, \mathrm{p}<0.001, \mathrm{n}=24$ ). As $\mathrm{NH}_{4}{ }^{+}$release ceased in some cores (mainly L/D cores), $\mathrm{NO}_{2}{ }^{-}$release also ceased.

\section{Flux of inorganic silicon}

Concentrations of $\mathrm{Si}(\mathrm{OH})_{4}$ were measured only at the end of the light period, and diel variations were not studied. Significantly lower flux rates (NK) out of the sediment were found for $L / D$ than dark cores (Fig. 5f), although for sandy cores the difference was significant (NK) only on the last day. Uptake of Si was observed only in the sandy cores. In the dark the outflux was 2 to 3 times higher (significant difference, NK) from the muddy than from the sandy sediment (ca 150 to 250 and 50 to $100 \mu \mathrm{mol} \mathrm{m} \mathrm{m}^{-2} \mathrm{~h}^{-1}$, respectively) (Fig. 5f), whereas no significant difference between mud and sand was found for the $\mathrm{L} / \mathrm{D}$ cores. A net uptake (max. $77 \mu \mathrm{mol} \mathrm{m}^{-2} \mathrm{~h}^{-1}$ ) was observed for some of the sandy $\mathrm{L} / \mathrm{D}$ cores, whereas there was always a net release of $\mathrm{Si}$ from the muddy sediment (Fig. 5f).

\section{Summary of differences between $24 \mathrm{~h}$ net fluxes}

For muddy sediment, significant differences in $24 \mathrm{~h}$ net fluxes between L/D and dark cores were found for
$\mathrm{O}_{2}$ and all measured nutrients except for $\mathrm{NO}_{3}{ }^{-}$(Table 2). In sandy sediment a significant difference was found for $\mathrm{NO}_{3}{ }^{-}$but not for $\mathrm{NO}_{2}{ }^{-}$or $\mathrm{O}_{2}$. Significant differences between $\mathrm{L} / \mathrm{D}$ and dark treatments usually occurred only in the latter part of the experiment. Even

Table 2. Summary of statistical tests on the effect of treatment and sediment type on mean $24 \mathrm{~h}$ flux of oxygen and inorganic nutrients in sediment cores

\begin{tabular}{|c|c|c|c|c|}
\hline \multirow[b]{2}{*}{ Variable } & \multicolumn{2}{|c|}{ L/D cycle vs dark } & \multicolumn{2}{|c|}{ Sand vs mud } \\
\hline & Sand & Mud & $L / D$ & Dark \\
\hline $\mathrm{O}_{2}$ & NS & · & NS & - \\
\hline $\mathrm{PO}_{4}{ }^{3-}$ & $\cdot$ & $\cdot$ & NS & $\cdot$ \\
\hline $\mathrm{NH}_{4}^{+}$ & $\cdot$ & . a & $\cdot$ & $\cdot$ \\
\hline $\mathrm{NO}_{3}^{-}$ & $\cdot a$ & NS & NS & $\cdot$ \\
\hline $\mathrm{NO}_{2}^{-}$ & NS & $\cdot$ & $\cdot$ & - \\
\hline $\mathrm{Si}(\mathrm{OH})_{4}$ & $\cdot$ & $\cdot$ & NS & $\cdot$ \\
\hline \multicolumn{5}{|c|}{$\begin{array}{l}\text { A significant difference (Newman-Keuls multiple com } \\
\text { parison test, } p<0.05 \text { ) found at least for } 1 \mathrm{~d} \\
\text { a Wilcoxon signed rank test }\end{array}$} \\
\hline
\end{tabular}

in the cases where significant differences could not be statistically supported, mean fluxes were generally lower for $L / D$ than for dark cores. Significant differences between $24 \mathrm{~h}$ net fluxes from muddy and sandy cores were observed for $\mathrm{O}_{2}$ and all nutrients in permanently darkened cores, but only for $\mathrm{NH}_{4}{ }^{+}$and nitrite in cores exposed to a $\mathrm{L} / \mathrm{D}$ cycle (Table 2). Statistical tests on the effect of 'bottom' and surface water were not possible because of the small number of replicates.

\section{Correlations between chlorophyll a, oxygen and nutrient fluxes}

The influence of algae and light on nutrient fluxes can be studied by plotting $\Delta$ nutrient flux rates (the differences in flux rates between light and dark periods in the L/D cores) against chlorophyll $a$ and $\Delta \mathrm{O}_{2}$ fluxes (Fig. 6). The best correlations were obtained when the most complete data sets from the first part of the experiment were used (Days 2 to 4 ). However, for $\Delta \mathrm{PO}_{4}$ flux, significant correlations were obtained when data from the whole experimental period were used.

$\Delta \mathrm{O}_{2}$ flux was strongly correlated with chlorophyll a content, i.e. the higher chlorophyll a content, the larger the $\Delta \mathrm{O}_{2}$ flux (Fig. 6a). A similar correlation was found with algal cell number $(\mathrm{r}=0.82, \mathrm{p}<0.001, \mathrm{n}=12)$. $\Delta \mathrm{PO}_{4}{ }^{3-}$ flux was better correlated with $\Delta \mathrm{O}_{2}$ flux (Fig. 6d) than with chlorophyll a content (Fig. 6c). For inorganic nitrogen ( $\mathrm{IN}_{i} \mathrm{NH}_{4}{ }^{-}+\mathrm{NO}_{2}{ }^{-}+\mathrm{NO}_{3}{ }^{-}$), significant correlations were found with both chlorophyll $a$ and 

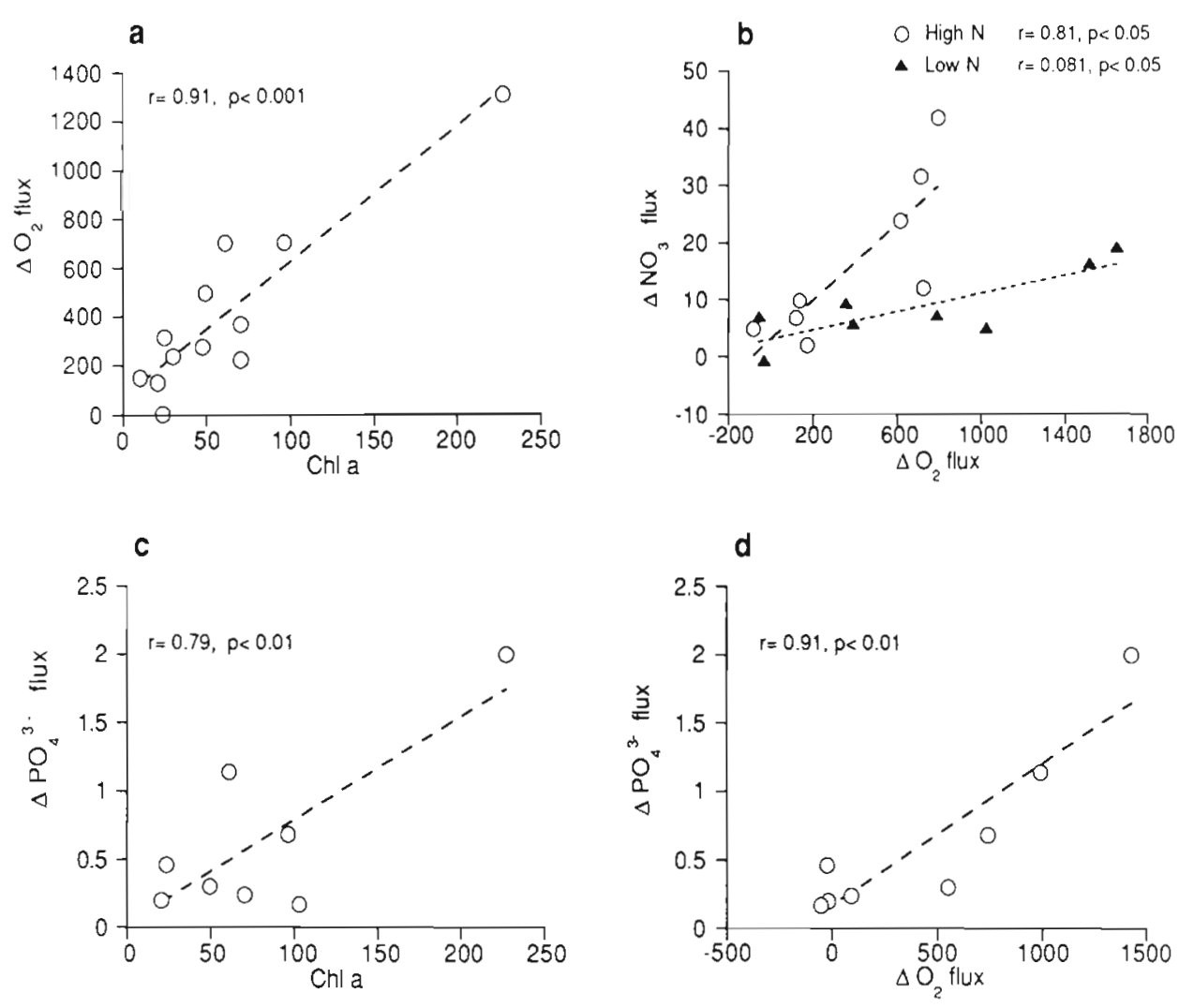

Fig. 6. Plots showing correlations between chlorophyll $a$ and $\Delta$ flux for oxygen and nutrients in $L / D$ cores. $\Delta$ oxygen flux $=$ day minus night flux, $\Delta$ nutrient fluxes $=$ night minus day flux. Oxygen vs Chl a (a); nitrate vs oxygen (b); phosphate vs Chl a (c); phosphate vs oxygen (d) ammonium vs Chl a (e); ammonium and IN vs oxygen (f)

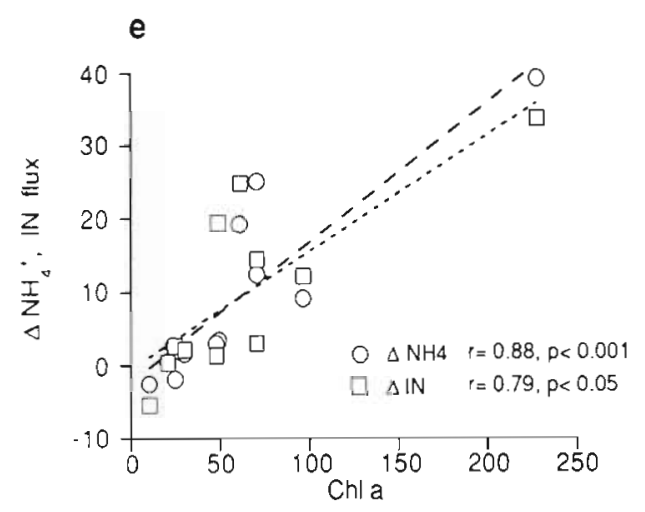

$\Delta \mathrm{O}_{2}$ flux, although $\Delta \mathrm{NH}_{4}^{+}$flux was more strongly correlated with chlorophyll a (Fig. 6e), whereas $\Delta$ IN correlated better with $\Delta \mathrm{O}_{2}$ flux (Fig. 6f). Furthermore, these plots revealed a higher $\Delta$ IN flux/chlorophyll a ratio in sand than in mud. During the latter part of the experiment 2 separate regressions were found for cores exposed to low and high nutrient water when $\Delta \mathrm{NO}_{3}{ }^{-}$ flux was plotted against chlorophyll and $\Delta \mathrm{O}_{2}$ flux, the correlation being stronger with $\Delta \mathrm{O}_{2}$ (Fig. 6b) than with chlorophyll a (not shown). No such difference between high and low nutrient treatments was found for $\triangle \mathrm{PO}_{4}{ }^{3-}$ flux (Fig. 6c, d). No significant correlation was found between $\Delta \mathrm{PO}_{4}{ }^{3-}$ and $\Delta$ IN flux (Fig. 7 ).

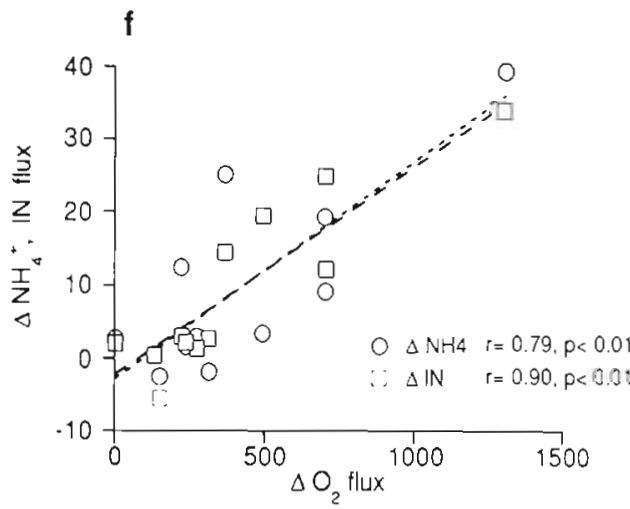

DISCUSSION

\section{Light-induced effects}

The diel variations in sediment-water flux of nutrients, i.e. a decreased outflux of $\mathrm{NH}_{4}{ }^{+}, \mathrm{NO}_{3}{ }^{-}$and $\mathrm{PO}_{4}{ }^{3-}$ during the light period, were shown to be mediated by photosynthetic benthic organisms. This conclusion is based on the fact that there was a light-induced benthic oxygen production as well as significant correlations between $\Delta \mathrm{O}_{z}$ flux (day minus night flux rate), the corresponding $\Delta$ nutrient fluxes (night minus day flux), the chlorophyll a content and the algal cell num- 


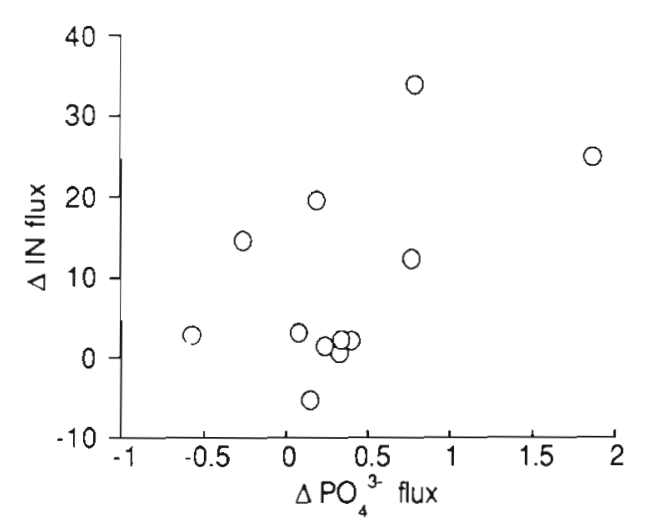

Fig. 7. $\Delta$ flux of inorganic nitrogen vs $\Delta$ flux of phosphate. For explanation of $\Delta$ flux see Fig. 6

bers in the sediment (Fig. 6). The significantly lower release of silicon from illuminated sediment also supports this conclusion and suggests that diatoms play a major role. Also, the differences in pore-water nutrient gradients between L/D and dark cores point to the importance of sediment-associated organisms. Our results agree with those of Carlton \& Wetzel (1988), who showed, by using ${ }^{32} \mathrm{P}$, that the efflux of $\mathrm{P}$ from the sediment was inversely related to the magnitude of microalgal photosynthesis. Similarly, Andersen \& Kristensen (1988) found an inverse relationship between the release of dissolved inorganic nitrogen and benthic primary production. The only unequivocal evidence of a light-induced effect on the algal biomass during our incubation was the higher cell numbers found in the sandy L/D cores compared with the sandy dark cores.

The diel variation in nutrient fluxes is coupled to the light-dark periods with at least 2 mechanisms: (1) algal uptake, (2) photosynthetic oxygen production. The microalgae are expected to assimilate more inorganic nutrients during the light period (Syrett 1981). Nutrient levels have been observed to be much lower in the biologically active thin top-most layer of the sediment than in both the overlying water and the sediment below, suggesting efficient removal mechanisms of nutrients from the interstitial water (Simon 1988 and references therein).

The oxygen produced by the benthic microalgae influences a number of microbial processes as well as purely chemical redox-reactions. The high-resolution microelectrode technique has enabled analysis of the variation in the sediment oxygen profile on microscales and the oxic/anoxic interface has been shown to rapidly move up and down with changed light conditions (Revsbech \& Jorgensen 1983, Lindeboom et al. 1985, Wit et al. 1989), affecting redox-sensitive flux processes (for further discussion see below).

Could biological processes, other than those related to the sediment organisms, have influenced the flux of nutrients and oxygen? Even if picoplankton and bacteria could have passed through the 1.2 um filter, the interference by biological processes in the very shallow column of headspace water was not likely to be important. The density of bacteria in sediments is generally ca 1000 times higher than that in the water phase (Meyer-Reil 1984), and this is also true for sedimentassociated microalgae. The primary productivity in the top $5 \mathrm{~mm}$ of illuminated sediment is, when expressed per unit area, within the same range as the phytoplankton productivity in a water column of several metres (e.g. Charpy-Roubaud \& Soumia 1990). Thus, it is unlikely that the microorganisms in the headspace water could have increased to densities high enough to overshadow, or even compete with, the effect of the sediment organisms. However, the growth of bacteria and benthic microalgae, mainly diatoms, on the walls of the perspex tubes might have interfered. This interference was, however, likely to be important only during the latter part of the experiment, whereas the diel fluctuations were observed already during the initial phase of the experiment. A brownish colouring. restricted to the stirring bar and a narrow zone in the top part of the tube, became visible only late in the experiment. This is consistent with observations that the growth rate of benthic diatoms (which dominated the algal biomass) is much lower (0.06 to $0.27 \mathrm{~d}^{-1}$; Gould \& Gallagher 1990) than that of phytoplankton species, and consequently, the colonization rate can be expected to be slow. Thus, the variations related to the L/D cycle appear to be mediated mainly by organisms within the sediment.

Several in situ investigations in intertidal and other shallow areas point to the fact that the microphytobenthos undoubtedly regulates nutrient flux between sediment and water (Vries \& Hopstaken 1984, Nowicki \& Nixon 1985, Asmus 1986, Kelderman et al. 1988, Keizer et al. 1989, Rizzo 1990). In our experiment, however, we dealt with sublittoral sediments from $15 \mathrm{~m}$ depth and the question arises as to the importance of microphytobenthos for total nutrient fluxes at this depth. Riaux-Gobin et al. (1989), who investigated 2 subtidal sediments at 10 and $20 \mathrm{~m}$ depth on the coast of Bretagne (France), found that the decrease of inorganic nitrogen in interstitial water in surface sediments was related to microphytobenthic spring bloom. Henriksen et al. (1981) interpreted the zero-flux of $\mathrm{NO}_{3}{ }^{-}$at $14 \mathrm{~m}$ depth in Kattegat as a result of uptake by a layer of benthic diatoms, and Jørgensen \& Revsbech (1989) recorded benthic photosynthesis at this depth. According to previous calculations by Granéli \& Sundbäck (1986), oxygen production by microphytobenthos (calculated from ${ }^{14} \mathrm{C}$ uptake values) may play a considerable role in Laholm Bay. The latter 3 studies represent a summer situation with adequate light conditions for 
microphytobenthic productivity at $15 \mathrm{~m}$ depth. At this depth, where usually less than $5 \%$ of surface irradiance remains, benthic primary productivity is negligible during October to April (Sundbäck \& Jönsson 1988). However, in lower latitudes, where light penetrates to greater depths during most of the year, the regulating mechanism of microphytobenthos can be expected to play a more important role than in northern temperate areas (cf. Plante-Cuny 1984, Hansen et al, 1987, Herndl et al. 1989).

\section{Oxygen flux}

Oxygen fluxes in this study were similar to rates reported for laboratory-incubated cores simulating conditions in Laholm Bay during summer (Granéli \& Sundbäck 1986). Benthic respiration rates for muddy cores were also similar to rates measured in situ for silty-sandy sediment from the northern Adriatic Sea sampled at depths of 15 and $22 \mathrm{~m}$ (Herndl et al. 1989). The mean gross primary production (here approximated by $\Delta \mathrm{O}_{2}$ flux) during the $16 \mathrm{~h}$ light period for Laholm Bay sediment was $420 \mu \mathrm{mol} \mathrm{O}_{2} \mathrm{~m}^{-2} \mathrm{~h}^{-1}$ and net production was $290 \mu \mathrm{mol} \mathrm{O} \mathrm{m}^{-1} \mathrm{~h}^{-1}$, which is similar to or somewhat lower than values for March to September at comparable or deeper sites in the Northern Adriatic Sea with noon light levels of 5 to $50 \mu \mathrm{E} \mathrm{m}^{-2} \mathrm{~s}^{-1}$ (Herndl et al. 1989). The microphytobenthic oxygen production in our laboratory study is thus not unrealistically high compared with in situ conditions at a depth of $15 \mathrm{~m}$. As the Kattegat has a mean depth of only $23 \mathrm{~m}$, the microphytobenthic algae may play a significant role in the regulation of oxygen conditions at the sedimentwater interface, as well as the nutrient exchange processes. The effect of microphytobenthic algae on oxygen conditions may be more dramatic than our measurements indicate, because diel changes in the interstitial water in the top few $\mathrm{mm}$ of the sediment may be much larger due to altered light conditions than the changes in the overlying water measured in this study (cf. Revsbech \& Jørgensen 1986, Jensen et al. 1984).

\section{Phosphorus flux}

The $\mathrm{PO}_{4}{ }^{3-}$ fluxes in this study agree with other measurements in the Kattegat, at $20 \mathrm{~m}$ and deeper (Enoksson et al. 1990), where both mud and especially sand released $\mathrm{PO}_{4}{ }^{3-}$ at rates that were low in proportion to oxygen consumption. This phenomenon has also been observed in Kiel Bight at $20 \mathrm{~m}$ depth (Balzer 1984) and in Chesapeake Bay (Boynton \& Kemp 1985).

The suppression of $\mathrm{PO}_{4}{ }^{3-}$ release in light occurred in both sandy and muddy samples, and in mud the light effect clearly continued also during the dark periods. As stated also by Carlton \& Wetzel (1988), the light-suppression of $\mathrm{PO}_{4}{ }^{3-}$ release may be due to oxygeninduced redox reactions and/or microphytobenthic uptake. As there was no correlation between oxygen concentration in the headspace water and $\mathrm{PO}_{4}{ }^{3-}$ flux during night in our experiment, oxygen may not have been the most important regulator of P-flux. On the other hand, if oxygen regulates the P-flux, it is probably the concentration gradient in the topmost few $\mathrm{mm}$ of the sediment that is important, not oxygen concentration in the bulk water above the sediment. Algal uptake of $\mathrm{PO}_{4}{ }^{3-}$, if taking place only during the day, does not fully fit our data, because the $\Delta \mathrm{O}_{2} / \Delta \mathrm{PO}_{4}{ }^{3-}$ flux ratio (cf. Fig. 6d) was much higher than both the Redfield ratio of 106 and the ratio 160 found by Brzezinski (1985), which is to be expected assuming the photosynthetic quotient to be 1. However, a $\mathrm{PO}_{4}{ }^{3-}$ uptake may have occurred also during night. Both $\mathrm{PO}_{4}{ }^{3-}$ uptake (Sundberg \& Nilshammer-Holmval 1975) and increase in cell phosphorus in the dark (Eppley et al. 1967) have been observed for microalgae, and therefore the net flux of $\mathrm{PO}_{4}{ }^{3-}$ over the whole light-dark cycle ( $24 \mathrm{~h}$ net flux) (Table 3) would compare better with the light induced changes in oxy-

Table 3. Mean $\mathrm{O}_{2}$ IN and $\mathrm{PO}_{4}{ }^{3-}$ fluxes for Day 2 and 4 given as net sediment water exchange rates for dark and L/D cores, differences in exchange rates between dark and L/D cores and atomic flux ratios calculated from these net fluxes and differences in net fluxes

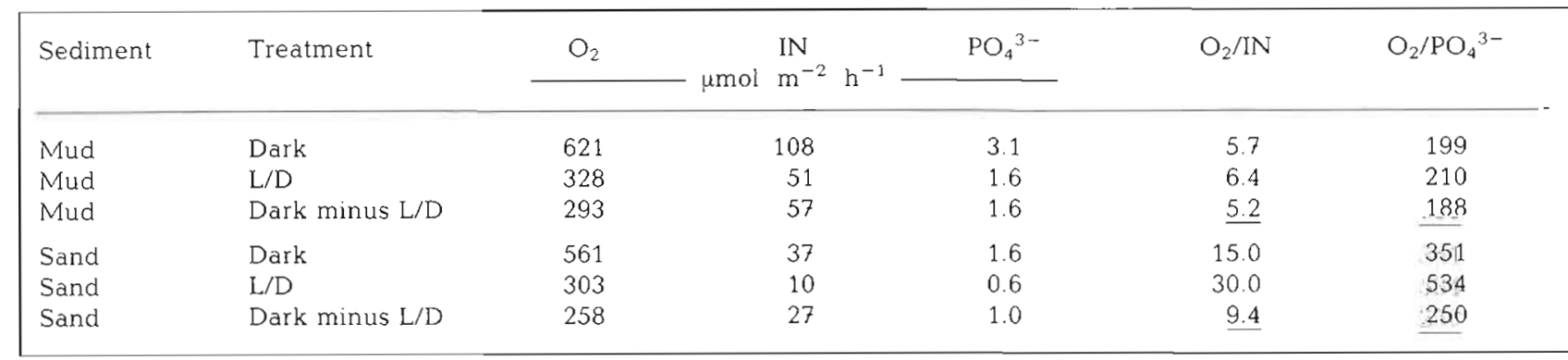


gen fluxes. In addition, heterotrophic activity that is stimulated by the organic carbon input from algal photosynthesis (Hall \& Fisher 1985, Andersen \& Kristensen 1988 ) would probably affect both day and night fluxes of $\mathrm{PO}_{4}{ }^{3-}$. Indeed, the differences in $24 \mathrm{~h}$ net $\mathrm{PO}_{4}{ }^{3-}$ fluxes between dark and L/D cores were similar to what would be predicted from the corresponding differences in oxygen fluxes, giving $\mathrm{O}_{2} / \mathrm{PO}_{4}{ }^{3-}$ ratios of 188 and 250 for mud and sand, respectively (Table 3 ). Therefore, there is no indication of a secondary, $\mathrm{O}_{2}$-mediated light effect on $\mathrm{PO}_{4}{ }^{3-}$ fluxes. Carlton \& Wetzel (1988) found that photosynthesis-mediated oxygen production was the main controlling factor for $\mathrm{PO}_{4}{ }^{3-}$ flux in carbonate-rich lake sediments, but there are important differences that prevent a direct application of their results on marine sediments. According to Caraco et al. (1990), in most salt-water systems $\mathrm{PO}_{4}{ }^{3-}$ is released from sediments and behaves essentially as a conservative tracer of benthic decomposition, while in freshwater systems $\mathrm{PO}_{4}{ }^{3-}$ is strongly immobilized in sediments under oxic conditions.

\section{Nitrogen fluxes}

The dark sandy sediment released IN at rates that were within the range observed for the same depths in July in the Kattegat (Blackburn \& Henriksen 1983) and in Aarhus Bight (Jensen et al. 1990). The high rates of IN release that we found for muddy cores has only been occasionally observed in Laholm Bay (Enoksson 1987. Enoksson et al. 1990).

Light efficiently decreased the release of $\mathrm{NH}_{4}{ }^{+}$, causing strong diel fluctuations in all samples where there was a high $\mathrm{NH}_{4}{ }^{+}$concentration in the overlying water, regardless if the sediment was sand or mud. Concurrent with a decreasing $\mathrm{NH}_{4}{ }^{+}$release, the $\mathrm{NO}_{3}{ }^{-}$flux exhibited enhanced diel fluctuations (Fig. 4C, d). $\mathrm{NH}_{4}{ }^{+}$was probably the nitrogen source that was preferred by the benthic microalgae, but when $\mathrm{NH}_{4}{ }^{+}$became less abundant, the algae started to utilize $\mathrm{NO}_{3}{ }^{-}$, which was available in adequate amounts in the headspace water of all cores.

As was found for the $\triangle \mathrm{PO}_{4}{ }^{3}$ - fluxes, the $\triangle \mathrm{IN}$ fluxes in $\mathrm{L} / \mathrm{D}$ cores were markedly lower than what would be expected from $\Delta \mathrm{O}_{2}$ fluxes (Fig. 6f). This might either indicate algal uptake of IN during night (Pettersson \& Sahlsten 1990) and/or that other microbial processes, indirectly affected by light, might have dampened the diel variations in the IN fluxes. The latter would include a stimulation of the strictly aerobic nitrifying bacteria via algal oxygen production, although there are also reports on nitrification being inhibited in algal mats (Henriksen \& Kemp 1988). Denitrification would also be affected in various ways, including (1) competition for $\mathrm{NO}_{3}{ }^{-}$by the algae, (2) changes in $\mathrm{NO}_{3}{ }^{-}$production, (3) stimulation by algal excretion of labile carbon compounds, (4) inhibition via algal oxygen production during daytime. The latter has been shown to be true for a stream sediment by Nielsen et al. (1990). If there was a similar inhibition of denitrification in our experiment, this would partly explain the low $\Delta$ IN fluxes.

The $24 \mathrm{~h}$ net fluxes of IN and $\mathrm{O}_{2}$ (Table 3) were used to calculate if algal uptake (incl. night uptake) could account for light effects on IN fluxes. $\mathrm{O}_{2} /$ IN ratios of 5.2 and 9.4 were obtained using the dark-L/D differences for mud and sand, respectively. The value for sand is close to 10, which would be expected for benthic microalgal activity ( $\mathrm{C} / \mathrm{N}$ atomic ratio of 10 , Brzezinski 1985). Therefore, we have no indication that light dependent mechanisms other than algal uptake were important in the sandy sediment. In mud, the relatively large light effect on IN flux (Dark-L/D; Table 3) may, however, point to a stimulation of denitrifiers during night in the $\mathrm{L} / \mathrm{D}$ cores, or to an increase in bacterial biomass, bacteria being much richer in protein than algae. $\mathrm{NO}_{2}{ }^{-}$ was released slightly faster during the light period but as $\mathrm{NO}_{2}{ }^{-}$is an intermediate product in a number of nitrogen transforming processes, we do not know the underlying mechanism. However, light had only a weak influence on the efflux of $\mathrm{NO}_{2}{ }^{-}$.

\section{Silicon flux}

Flux of silicon is not considered to be directly influenced by redox-conditions (Balzer 1984). Therefore silicon has often been used as a conservative tracer to evaluate the magnitude of sedimentary fluxes (e.g. Ullman \& Aller 1989). However, the potential uptake of silicon by diatoms at the sediment-water interface has not been considered. Our flux measurements revealed a markedly lower Si outflux in L/D than in dark cores, thus giving us a measure of algal activity not masked by either oxygen conditions or heterotrophic processes. The silicon fluxes show that diatoms play an important role in the nutrient flux between sediment and water. Kelderman et al. (1988) reported results indicating that the growth of benthic diatoms can be limited by silica availability.

\section{Nutrient fluxes and sediment type}

In the dark, the outflow of inorganic nutrients was significantly higher from the muddy than from the sandy sediment. This agrees with Enoksson's (1987) measurements of nutrient fluxes for sediments from Laholm Bay and with other results (e.g. Nowicki \& Nixon 1985, Ullman \& Sandstrom 1987). In the L/D cores, on the other hand, the mean 24 h net fluxes were only occasionally higher in mud (Table 2). This may be 
a result of the higher microalgal activity in muddy than in sandy sediment during the light period. This conclusion is corroborated by the higher chlorophyll a content and algal cell numbers in the mud (Table 1) in combination with higher $\Delta \mathrm{O}_{2}$ fluxes.

Muddy cores released exceptionally large amounts of $\mathrm{NO}_{2}{ }^{-}$, the source of which was most probably $\mathrm{NH}_{4}{ }^{+}$. There appears to be a mechanism operating in the muddy sediment that blocks the further conversion of $\mathrm{NO}_{2}{ }^{-}$, either to nitrogen gas or to $\mathrm{NO}_{3}{ }^{-}$(or $\mathrm{NH}_{4}{ }^{+}$). Muddy sediment was characterized by a rather high organic content (around $4 \%$ org. C), a high oxygen consumption, probably an ephemeral nature of the muddy layer (Flodérus \& Håkanson 1989), and absence of bioturbation. In darkness, such a sediment would only be oxic in the top few millimeters (Jørgensen \& Revsbech 1985), and only there would $\mathrm{NH}_{4}{ }^{+}$oxidation take place. If a close coupling between $\mathrm{NH}_{4}{ }^{+}$oxidizing and $\mathrm{NO}_{2}{ }^{-}$oxidizing bacteria is lacking, a large fraction of the produced $\mathrm{NO}_{2}{ }^{-}$would diffuse out into the water, where the abundance of $\mathrm{NO}_{2}{ }^{-}$oxidizers is lower than in the sediment. In addition, the low release, or even uptake, of $\mathrm{NO}_{3}{ }^{-}$by the sediment, suggests that the $\mathrm{NO}_{2}{ }^{-}$oxidizers were not fully established or that they were inhibited by reduced sulphur compounds (Bremner \& Bundy 1974). $\mathrm{NO}_{3}{ }^{-}$reducers, especially those that are able to produce $\mathrm{NH}_{4}{ }^{-}$and that accumulate $\mathrm{NO}_{2}{ }^{-}$(Samuelsson et al. 1988), are believed to thrive in highly organic sediments and therefore cannot be ruled out as the responsible group. However, our failure to show any dependence of $\mathrm{NO}_{2}{ }^{-}$on $\mathrm{NO}_{3}{ }^{-}$ concentrations strongly suggests that $\mathrm{NO}_{2}{ }^{-}$is produced directly by $\mathrm{NH}_{4}{ }^{+}$oxidizers.

\section{Surface vs bottom water}

No stimulation of microbenthic algae from higher nutrient concentrations in the simulated below-halocline water was found. This agrees with previous experiments with muddy sublittoral sediment from Laholm Bay (Sundbäck 1986). For sandy sediment, however, nutrient limitation of microphytobenthos has been shown both for shallow water (Nilsson et al. 1991) and for sediment from $15 \mathrm{~m}$ depth in Laholm Bay (Granéli \& Sundbäck 1985, Sundbäck 1986, Sundbäck \& Granéli 1988). The lack of response of the microflora to the nutrient enrichment of the overlying water may have several explanations: (1) Nutrient release by the sediment itself may have overshadowed a possible stimulatory effect on algal growth by the enriched overlying water. The fact that the release of both $\mathrm{IN}$ and $\mathrm{PO}_{4}{ }^{3-}$ from muddy sediment during the dark period was within the same range as the input rate of nutrients in the inflowing water, supports this idea. Adding much higher amounts of nutrients to the overlying water did, however, stimulate the algal population of sandy sublittoral sediment (Sundbäck 1986). It appears that the high abundance of microalgae observed below the halocline in Laholm Bay (Sundbäck \& Jönsson 1988) is instead related to the nutrient supply from the sediment itself rather than the concentration in the overlying water. (2) Because of the low light quantity used in the experiment, the algae may have been light rather than nutrient limited. Production vs light (P/I) curves for sublittoral microbenthic algae from Laholm Bay, showed that algae were light limited below depths of $5 \mathrm{~m}$ (Sundbäck \& Jönsson 1988). (3) The duration of the experiment (14 d) may have been too short to reveal a stimulatory effect. The response of sediment-associated microalgae to changed nutritional conditions appears to exhibit a minimum lag time of ca $2 \mathrm{wk}$, suggesting that the sediment system is fairly well buffered against shortterm environmental changes (Levinton 1985, Sundbäck et al. 1990, Nilsson et al. 1991, Lindström Swanberg in press). Significant differences in nutrient fluxes between treatments were usually recorded only during the latter part of the experiment, which supports this conclusion. (4) Finally, a possible stimulating effect of the enriched bottom water could also have been masked because of the high individual variation among the cores and because we could not follow the development of the microphytobenthos in the individual cores during the experiment.

\section{Faunal activity}

We used cores without macrofauna. The accidental inclusion of one core containing a mussel demonstrated the effect of animal activity (in this case a suspensionfeeder) by increased release of $\mathrm{NH}_{4}{ }^{+}$(Fig. 4c) and $\mathrm{PO}_{4}{ }^{3-}$ (Fig. 4b). The question is, whether animal excretion and bioturbation can overshadow the influence of microalgae in situ. Kelderman et al. (1988) found no differences in $\mathrm{P}$ and $\mathrm{Si}$ fluxes between dark and light bell jars when placed over a dense cockle field with low primary productivity. On the other hand, Henriksen et al. (1980), Asmus (1986), Andersen \& Kristensen (1988), and Lindström Swanberg (in press) all observed significant effects of microphytobenthos on nutrient fluxes in sediments with natural densities of macrofauna.

\section{CONCLUSIONS}

(1) Our results suggest that diel oscillations of nutrient fluxes related to the light/dark cycle can occur even at sublittoral depths (15 m). (2) These diel oscillations, with decreased outflux of both IN and $\mathrm{PO}_{4}{ }^{3-}$ during the light period, were shown to be mediated by 
photosynthetic organisms. (3) Significantly lower outflux, or even uptake of silicon from cores exposed to a L/D cycle also supports this conclusion and indicates that diatoms play a major role for the nutrient flux between sediment and water. (4) In the sublittoral sediment used in this experiment, IN flux mainly appeared to be directly influenced by algal uptake. Furthermore, $\mathrm{PO}_{4}{ }^{3-}$ flux appeared to a higher degree to depend on algal uptake than on changes in the redox conditions mediated by photosynthesis. (5) Although microphytobenthos appears to regulate nutrient flux even at sublittoral depths, this effect is probably limited to the growth season, when enough light penetrates to the sediment surface. (6) Our results suggest, that when studying nutrient flux in permanently darkened cores, the flux rates will, in the summer, be overestimated by a factor of 2 to 6 , depending on sediment type. (7) In shallow water, where light reaches the bottom, flux measurements should be made under light conditions corresponding to those in situ.

Acknowledgements. The experiment was conducted at the Department of Marine Microbiology, University of Göteborg, Sweden. The technical assistance of Anna-Kerstin Thell is acknowledged. Michael Wrangstad and Grim Pedersen dived for the cores. Per Nilsson (Tjärnö Marine Biological Laboratory) gave guidance on the application of statistical analysis. Financial support was provided by the Swedish National Nature Protection Agency.

\section{LITERATURE CITED}

Aller, R. C. (1988). Benthic fauna and biogeochemical processes in marine sediments. The role of burrow structures. In: Blackburn, T H., Sørensen, J. (ed.) Nitrogen cycling in coastal marine environments. John Wiley \& Sons, Chichester, p. 301-338

Andersen, F. O., Kristensen, E. (1988). The influence of macrofauna on estuarine benthic community metabolism: a microcosm study. Mar. Biol. 99: 591-603

Asmus, R. (1986). Nutrient flux in short-term enclosures of intertidal sand communities. Ophelia 26: 1-18

Balzer, W. (1984). Organic matter degradation and biogenic element cycling in a nearshore sediment (Kiel Bight). Limnol. Oceanogr 29: 1231-1246

Blackburn, T H., Henriksen., K. (1983). Nitrogen cycling in different types of sediments from Danish waters. Limnol. Oceanogr 28: 477-493

Bodin, P. D., Boucher, J., Guillou, J., Guillou, M. (1985). The trophic system of the benthic communities in the bay of Douarnenez (Brittany). In: Gibbs, P. E. (ed.) Proceedings 19th European Marine Biology Symposium. Cambridge University Press, Cambridge, p. 361-370

Boynton, W. R., Kemp, W M. (1985). Nutrient regeneration and oxygen consumption by sediments along an estuarine salinity gradient. Mar Ecol. Prog. Ser. 23: 45-55

Bremner, J. M., Bundy, L. G. (1974). Inhibition of nitrification in soils by volatile sulfur compounds. Soil Biol. Biochem. 6 : 161-165

Brzezinski, M. A. (1985). The Si: C:N ratio of marine diatoms: interspecific variability and the effect of some environmental variables. J. Phycol. 21: 347-357

Caraco, N., Cole, J., Likens, G. E. (1990). A comparison of phosphorus immobilization in sediments of freshwater and coastal marine systems. Biogeochemistry 9: 277-290

Carlton, R. G., Wetzel, R. G. (1988). Phosphorus flux from lake sediments: effect of epipelic algal oxygen production. Limnol. Oceanogr 33: 562-570

Charpy-Roubaud, C., Sournia, A. (1990). The comparative estimation of phytoplanktonic, microphytobenthic and macrophytobenthic primary production in the oceans. Mar Microb. Food Webs 4: 31-57

Enoksson, $V$ (1987). Nitrogen flux between sediment and water and its regulatory factors in coastal areas. Ph.D. thesis, University of Göteborg

Enoksson, V., Samuelsson, M.-O. (1987). Nitrification and dissimilatory ammonium production and their effects on nitrogen flux over the sediment-water interface in bioturbated coastal sediments. Mar. Ecol. Prog. Ser. 36: 181-189

Enoksson, V., Sörensson, F., Granéli, W (1990). Nitrogen transformations in the Kattegat. Ambio 19: 159-166

Eppley, R. W., Holmes, R. W., Paasche, E. (1967). Periodicity in cell division and physiological behaviour of Ditylum brightwellii, a marine planktonic diatom, during growth in light-dark cycle. Archiv Mikrobiol. 56: 305-323

Flodérus, S., Håkanson, L. (1989). Resuspension, ephemeral mud blankets and nitrogen cycling in Laholmsbukten, south east Kattegat. Hydrobiologia 176/177: 61-75

Gould, D. M., Gallagher, E. D. (1990). Field measurements of specific growth rate, biomass, and primary production of benthic diatoms of Savin Hill Cove, Boston. Limnol. Oceanogr. 35: 1757-1770

Granéli, E., Sundbäck, K. (1985). The response of planktonic and microbenthic algal assemblages to nutrient enrichment in shallow coastal waters, southwest Sweden. J. exp. mar. Biol. Ecol. 85: 253-268

Granéli, W, Sundbäck, K. (1986). Can microbenthic photosynthesis influence below-halocline oxygen conditions in the Kattegat? Ophelia 26: 195-206

Grasshoff, K., Ehrhardt, M., Kremling, K. (1983). Methods of seawater analysis, 2nd edn. Verlag Chemie, Weinheim

Green, R. H. (1979). Sampling design and statistical methods for environmental biologists. John Wiley and Sons, New York

Hall, S. L., Fisher, F. M. Jr (1985). Annual productivity and extracellular release of dissolved organic compounds by the epibenthic algal community of a brackish marsh. Phycol. $21 \quad 277-281$

Hansen, J. A., Alongi, D. M., Moriarty, D. J. W. Pollard, P. C. (1987). The dynamics of benthic microbial communities at Davies Reef, central Great Barrier Reef. Coral Reefs 6: 63-70

Hansson, L. A. (1989). Structuring forces for periphytic and planktonic algal biomass development. Ductoral thesis, University of Lund

Henriksen, K., Kemp, W. M. (1988). Nitrification in estuarine and coastal marine sediments. In: Blackburn, T H., Srrensen, J. (eds.) Nitrogen cycling in coastal marine environments. John Wiley \& Sons, Chichester, p. 207-249

Henriksen, K., Hansen, J. I., Blackburn, T H. (1980). The influence of benthic infauna on exchange rates of norganic nitrogen between sediment and water Ophelia, Suppl. 1: 249-256

Henriksen, K., Hansen, J. I., Blackburn, T H. (1981). Rates of nitrification, distribution of nitrifying bacteria, and nitrate fluxes in different types of sediment from Danish waters. Mar. Biol. 61: 299-304

Herndl, G. J., Peduzzi, P., Fanuko, N. (1989). Benthic community metabolism and microbial dynamics in the Gulf of 
Trieste (Northern Adriatic Sea). Mar. Ecol. Prog. Ser 53: $169-178$

Jensen, H. B., Jørgensen, K. S., Sorensen, J. (1984). Diurnal variation of nitrogen cycling in coastal, marine sediments II. Nitrous oxide emission. Mar Biol. 83: 177-183

Jensen, M. H., Lomstein, E., Sorensen, J. (1990). Benthıc $\mathrm{NH}_{4}{ }^{+}$ and $\mathrm{NO}_{3}{ }^{-}$flux following sedimentation of a spring phytoplankton bloom in Aarhus Bight, Denmark. Mar Ecol. Prog. Ser. 61: 87-96

Jørgensen, B. B., Revsbech, N.-P. (1985). Diffusive boundary layers and the oxygen uptake of sediments and detritus. Limnol. Oceanogr. 30: 111-122

Jørgensen, B. B., Revsbech, N. P. (1989). Oxygen uptake, bacterial distribution, and carbon-nitrogen-sulfur cycling in sediments from the Baltic Sea - North Sea transition. Ophelia 31. 29-49

Keizer, P. D., Hargrave, B. T., Gordon, D. C., Jr (1989). Sediment-water exchange of dissolved nutrients at an intertidal site in the upper reaches of the Bay of Fundy. Estuaries 12: 1-12

Kelderman, P., Lindeboom, H. J., Klein, J. (1988). Light dependent sediment-water exchange of dissolved reactive phosphorus and silicon in a producing microflora mat. Hydrobiologia 159: 137-147

Levinton, J. S. (1985). Complex interactions of a deposit feeder with its resources: roles of density, a competitor, and detrital addition in the growth and survival of the mudsnail Hydrobia totteni. Mar. Ecol. Prog. Ser. 22: 31-40

Lindeboom, H. J., Sandee, A. J. J., deKlerk-v.d. Driessche, H. A. J. (1985). A new belljar/microelectrode method to measure changing oxygen fluxes in illuminated sediments with a microalgal cover Limnol. Oceanogr. 30: 693-698

Lindström Swanberg, I. (in press). The influence of the filterfeeding bivalve Cerastoderma edule L. on benthic primary producers: a laboratory study. J. exp. mar. Biol. Ecol.

Lorenzen, C. J. (1967). Determination of chlorophyll and pheopigments: spectrophotometric equations. Limnol. Oceanogr. 12: 343-346

Meyer-Reil, L.-A. (1984). Bacterial biomass and heterotrophic activity in sediments and overlying waters. In: Hobbie, J. E., Williams, P. J. LeB. (eds.) Heterotrophic activity in the sea. NATO Conference Series. Series IV Marine sciences. Plenum Press, New York, p. 532-546

Nielsen, L. P., Christensen, P. B., Revsbech, N. P., Sorensen, J. (1990). Denitrification and photosynthesis in stream sediment studied with microsensor and whole-core techniques. Limnol. Oceanogr 35: 1135-1144

Nilsson, P., Jönsson, B., Lindström Swanberg, I., Sundbäck, K (1991). Response of a marine shallow-water sediment system to increased load of inorganic nutrients. Mar Ecol. Prog. Ser. 71. 275-290

Nixon, S. W. (1981). Remineralization and nutrient cycling in coastal marine ecosystems. In: Neilson, B. J., Cronin, L. E. (eds.) Estuaries and nutrients. Humana Press, Clifton, New Jersey, p. 111-138

Nowicki, B. L., Nixon, S. W. (1985). Benthic nutrient remineralization in a coastal lagoon ecosystem. Estuaries 8: 182-190

Pettersson, K., Sahlsten, E. (1990). Diel patterns of combined nitrogen uptake and intracellular storage of nitrate by phytoplankton in the open Skagerrak. J. exp. mar. Biol. Ecol. 138: 167-182

Plante-Cuny, M.-R. (1984). Le microphytobenthos et son role à l'échelon primaire dans le milieu marin. Oceanis 10: $417-427$

This article was submitted to the editor
Propp, M. V., Garber, M. R., Ryabusco, V. I. (1982). Unstable processes in the metabolic rate measurements in flowthrough systems. Mar. Biol. 67: 47-49

Revsbech, N.-P., Jorgensen, B. B. (1983). Photosynthesis of benthic microflora measured with high spatial resolution by the oxygen microprofile method: capabilities and limitations of the method. Limnol. Oceanogr 28: 749-756

Revsbech, N.-P., Jorgensen, B. B. (1986). Microelectrodes: their use in microbial ecology. In: Marshall, K. C. (ed.) Adv. microb. Ecol. Vol 9. Plenum New York, p. 293-352

Riaux-Gobin, C., Douchement, C., Treguer, P. (1989). Microphytobenthos de deux sédiments subtidaux de Nord Bretagne. III. Relations avec les sels minéraux azotés de l'eau interstitielle et deux facteurs hydroclimatiques. Hydrobiologia 178: 11-20

Rizzo, W. M. (1990). Nutrient exchanges between the water column and a subtidal benthic microalgal community Estuaries 13: 219-226

Samuelsson, M.-O., Cadez, P., Gustafsson, L. (1988). Heat production by the denitrifying bacterium, Pseudomonas fluorescens, and the dissimilatory ammonium producing bacterium, Pseudomonas putrefaciens, during anaerobic growth with nitrate as the electron acceptor. Appl environ. Microbiol. 54: 2220-2225

Simon, N. S. (1988). Nitrogen cycling between sediment and the shallow-water column in the transition zone of the Potomac River and Estuary. I. Nitrate and ammonium fluxes. Estuar. coast Shelf Sci. 26: 483-497

Stevenson, R. J., Stoermer, E. F. (1981). Quantitative differences between benthic algal communities along a depth gradient in Lake Michigan. J. Phycol. 17: 29-36

Sundbäck, K. (1986). What are the benthic microalgae doing on the bottom of the Laholm Bay? Ophelia, Suppl. 4: $273-286$

Sundbäck, K., Granéli, W. (1988). Influence of microphytobenthos on the nutrient flux between sediment and water: a laboratory study. Mar Ecol. Prog. Ser 43: 63-69

Sundbäck, K., Jönsson, B. (1988). Microphytobenthic productivity and biomass in sublittoral sediments of a stratified bay southeastern Kattegat. J. exp. mar. Biol. Ecol. 122: 63-81

Sundbäck, K., Jönsson, B., Nilsson, P., Lindström, I. (1990) Impact of accumulating drifting macroalgae on a shallowwater sediment system: an experimental study. Mar Ecol. Prog. Ser. 58: 261-274

Sundberg, I., Nilshammer-Holmvall, M. (1975). The diurnal variation in relation to deposition of starch, lipid, and polyphosphate in synchronized cells of Scenedesmus. Z PflPhysiol. 76: 270-279

Syrett, P. J. (1981). Nitrogen metabolism of algae. Can. Bull Fish. Aquat. Sci. 210: 182-210

Ullman, W. J., Aller, R. C. (1989). Nutrient release rates from the sediments of Saginaw Bay, Lake Huron. Hydrobiologia 171: $127-140$

Ullman, W J., Sandström, M. W. (1987). Dissolved nutrient fluxes from the nearshore sediments of Browling Green Bay, Central Great Barrier Reef Lagoon (Australia). Estuar. Coast. Shelf Sci. 24: 289-303

Vries, I. de, Hopstaken, C. F. (1984). Nutrient cycling and ecosystem behaviour in a salt-water lake. Neth. J. Sea Res. 18: 221-245

Wit, R. de, Jonkers, H. M, van den Ende, F. P., van Gemerden, H. (1989). In situ fluctuations of oxygen and sulphide in marine microbial sediment ecosystems. Neth. J. Sea Res. 23: $271-281$

Manuscript first received: February 5, 1991

Revised version accepted: May 30,1991 